Article

\title{
Monitoring Reservoir Drought Dynamics with Landsat and Radar/Lidar Altimetry Time Series in Persistently Cloudy Eastern Brazil
}

\author{
Jamon Van Den Hoek ${ }^{1, *(1)}$, Augusto Getirana ${ }^{2,3}$, Hahn Chul Jung ${ }^{3,4}(\mathbb{D}$, \\ Modurodoluwa A. Okeowo ${ }^{5}$ and Hyongki Lee ${ }^{5}$ (D) \\ 1 Geography Program, College of Earth, Ocean, and Atmospheric Sciences, Oregon State University, \\ Corvallis, OR 97331, USA \\ 2 Earth System Science Interdisciplinary Center, University of Maryland, College Park, MD 20740, USA; \\ augusto.getirana@nasa.gov \\ 3 Hydrological Sciences Laboratory, NASA Goddard Space Flight Center, Greenbelt, MD 20771, USA; \\ hahnchul.jung@nasa.gov \\ 4 Science Systems and Applications, Inc., Lanham, MD 20706, USA \\ 5 Department of Civil and Environmental Engineering, University of Houston, Houston, TX 77005, USA; \\ maokeowo@uh.edu (M.A.O.); hlee@uh.edu (H.L.) \\ * Correspondence: vandenhj@oregonstate.edu
}

Received: 5 March 2019; Accepted: 4 April 2019; Published: 6 April 2019

check for updates

\begin{abstract}
Tropical reservoirs are critical infrastructure for managing drinking and irrigation water and generating hydroelectric power. However, long-term spaceborne monitoring of reservoir storage is challenged by data scarcity from near-persistent cloud cover and drought, which may reduce volumes below those in the observational record. In evaluating our ability to accurately monitor long-term reservoir volume dynamics using spaceborne data and overcome such observational challenges, we integrated optical, lidar, and radar time series to estimate reservoir volume dynamics across 13 reservoirs in eastern Brazil over a 12-year (2003-2014) period affected by historic drought. We (i) used 1560 Landsat images to measure reservoir surface area; (ii) built reservoir-specific regression models relating surface area and elevation from ICESat GLAS and Envisat RA-2 data; (iii) modeled volume changes for each reservoir; and (iv) compared modeled and in situ reservoir volume changes. Regression models had high goodness-of-fit (median RMSE $=0.89 \mathrm{~m}$ and $\mathrm{r}=0.88$ ) across reservoirs. Even though $88 \%$ of an average reservoir's volume time series was based on modeled area-elevation relationships, we found exceptional agreement (RMSE $=0.31 \mathrm{~km}^{3}$ and $\left.\mathrm{r}=0.95\right)$ with in situ volume time series, and accurately captured seasonal recharge/depletion dynamics and the drought's prolonged drawdown. Disagreements in volume dynamics were neither driven by wet/dry season conditions nor reservoir capacity, indicating analytical efficacy across a range of monitoring scenarios.
\end{abstract}

Keywords: reservoir volume; clouds; Envisat; ICESat; time series

\section{Introduction}

Reservoirs are critical global infrastructure that occupy at least $26 \times 10^{4} \mathrm{~km}^{2}(0.2 \%)$ of global land surface area and contribute $6 \times 10^{3} \mathrm{~km}^{3}(0.0004 \%)$ of global freshwater storage [1]. The freshwater held by reservoirs is essential for meeting global demand for drinking water, irrigation water for agriculture [2,3], and hydroelectric power generation [4]. Recent research has identified the dual roles of reservoirs in atmospheric carbon dynamics being large-scale sites of both carbon sequestration as well as greenhouse gas emission [5-11]. Tropical reservoirs only make up 15\% (1040) of the 
6824 Global Reservoir and Dam (GRanD) Database reservoirs [12] but play a relatively outsized role in atmospheric carbon flux compared to temperate reservoirs [13-18]. Consistent, systematic, and long-term monitoring of reservoir storage throughout drought as well as high precipitation periods is essential to understanding the role of tropical reservoirs on society and environment $[8,16])$.

Reservoir storage is temporally dynamic and satellite remote sensing time series from optical (e.g., Landsat, MODIS, Sentinel-2) and radar or lidar (e.g., Envisat, GLAS/ICESat) systems support systematic monitoring of changes in reservoir volume at low cost per reservoir [19-27]. Spaceborne observation of reservoir dynamics are especially valuable for geographically remote or high-elevation reservoirs where consistent and long-term monitoring are a challenge, or in regions where the cost of constructing or maintaining a hydrologic gauge network is prohibitively expensive [28-30]. However, optical remote sensing of tropical reservoir dynamics is complicated by persistent cloud cover [31-33]. Indeed, as shown in Figure 1, the 178 Brazilian reservoirs included in GRanD are on average obscured by clouds $54 \%$ of days between 2003 and 2014 .

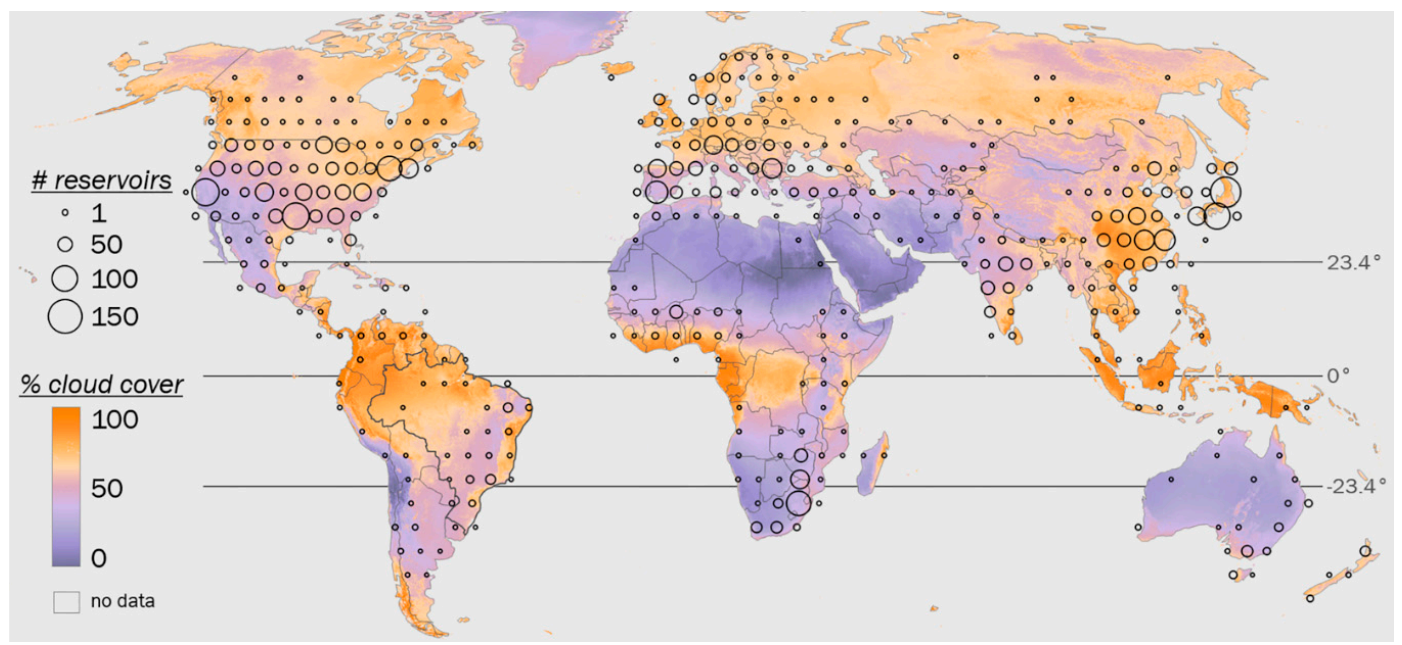

Figure 1. Global distribution of Global Reservoir and Dam (GRanD) Database reservoirs [12]. Reservoir counts are summarized at $5^{\circ}$ resolution), and percent daily cloud cover is based on MODIS MOD09GA [34] (2003-2014, 1 km resolution, Robinson projection).

In addition to the challenges of persistent cloud cover, monitoring long-term tropical reservoir dynamics is complicated by sensor spatial resolution, satellite revisit period, and, in some cases, a limited observational record. MODIS has regularly been used to monitor reservoir dynamics at sub-monthly time scales (e.g., [23,25,35]). While spectral unmixing of MODIS imagery has been effective at measuring sub-pixel fractional water area [36,37], the relatively coarse $250 \mathrm{~m}$ spatial resolution impedes detection of the reservoir edge and quantification of fine-scale surface area changes (e.g., [38]) with heightened consequences for reservoirs with shallow sloped near-surface bathymetry [25]. Landsat's $30 \mathrm{~m}$ spatial resolution, over 40 years of global coverage makes it well suited for long-term, high spatial resolution monitoring of reservoir surface water dynamics [39-43]. Unfortunately, Landsat's 16-day revisit period limits the opportunities to mitigate cloud cover or haze compared to 8- or 16-day MODIS temporal composites [44], which further restricts opportunities for pairing surface area estimates with concurrent altimetry elevation observations. While spaceborne radar is broadly robust to atmospheric effects, altimeters on TOPEX/Poseidon and Jason-1, 2, and 3 satellites with 3-10 km spatial resolutions are not well suited for monitoring smaller reservoirs [45,46]. More recent platforms such as and Cryosat-2 and Sentinel 3 have higher spatial resolution but lack long-term coverage $[24,47,48]$. However, Envisat RA-2 (Radar Altimeter 2) radar (2002-2012) and ICESat GLAS (Geoscience Laser Altimeter System) lidar (2003-2010) altimeters lend themselves to reservoir monitoring applications given their sub-kilometer resolution and many years of coverage $[28,35,49-52]$. 
Using a case study of 13 reservoirs in eastern Brazil, the goal of this study is to accurately model tropical reservoir volume dynamics from 2003 to 2014 despite near-persistent cloud cover and reservoir depletion due to a historic drought in 2014. To achieve our goal, we estimated surface area and elevation across study reservoirs by integrating Landsat, Envisat RA-2, and ICESat GLAS time series, modeling surface area-elevation relationship, calculating volume changes over the study period, and assessing agreement between modeled and in situ volume time series data per date, month, and year with attention to differences in agreement before and during the drought.

\section{Materials and Methods}

\subsection{Study Area}

Brazil is the largest ( 8.5 million $\mathrm{km}^{2}$ ) and most populous country (approximately 209 million residents in 2017) in South America. The country is dominated by tropical rain forest in its west and north, has tropical semideciduous forest along its southeastern Atlantic coast with tropical savannas (cerrado) stretching between the Brazilian Highlands to the Mato Grosso Plateau, and is home to major urban population centers including São Paulo, Rio de Janeiro, and the capital, Brasilia, in the eastern half of the country. Brazil has the largest reserve of renewable surface water in the world, approximately $32 \%$ of which is used for agricultural production [53]. Beginning in 2012, changing atmospheric circulation patterns, declining rainfall, and increased temperatures culminated in the summer of 2014 being the warmest and driest since 1951 [54] and a series of historically intense droughts that parched extensive cropland, dwindled drinking water supply, and shrank Brazil's rivers and reservoirs [55,56].

During the peak of the drought in the summer of 2014, national hydroelectric production declined by approximately 20\% compared to average 2000-2010 levels, and the Cantareira reservoir system relied upon by São Paulo saw nearly 11\% reduction in its total capacity [53]. Over half of Brazil's largest reservoirs (by hydroelectric production) are located in the drought-affected eastern region of the country. Thirteen reservoirs were included in this study that span southeast Brazil (Figure 2) with at least three dates of observation between Envisat and GLAS. Four study reservoirs-Agua Vermelha, Furnas, Marimbondo, and Tres Marias-with a range in nominal storage capacity from 1.3 to $34.1 \mathrm{~km}^{3}$ and a diversity of inter-annual storage dynamics were selected for focused data presentation below with the remaining reservoirs' data included in the Appendix A.

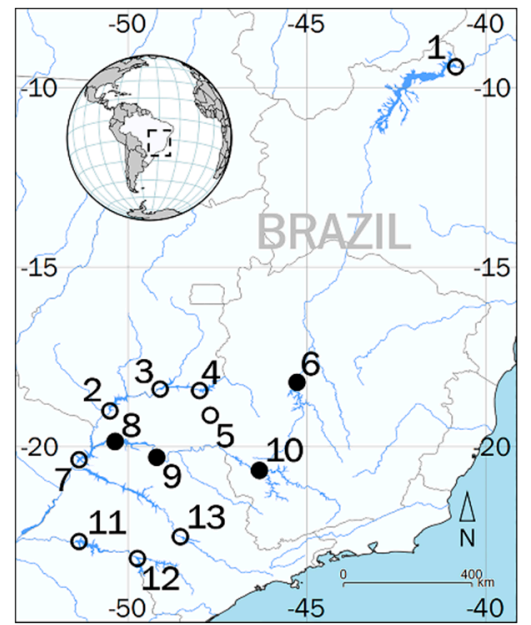

study reservoir $\left(\mathrm{km}^{3}\right)$
1 Sobradinho $(34.1)$
2 Sao Simao $(12.5)$
3 Itumbira $(17.0)$
4 Emborcacao $(17.6)$
5 Nova Ponte $(1.3)$
6 Tres Marias* $(21.0)$
7 Ilha Solteira $(21.2)$
8 Agua Vermelha* $(11.0)$
9 Marimbondo* $(6.2)$
10 Furnas* $(22.6)$
11 Capivara $(10.5)$
12 Chavantes $(8.8)$
13 Barra Bonita $(2.6)$

Figure 2. Geographic distribution and storage capacities $\left(\mathrm{km}^{3}\right)$ of study reservoirs in eastern Brazil [12]. Four focus reservoirs whose volume dynamics are illustrated in the manuscript text are identified with a black point on the map and an asterisk $\left(^{*}\right)$ in the reservoir list; all reservoirs' dynamics are illustrated in Appendix A. 


\subsection{Modeling Framework}

The volumetric modeling framework (Figure 3) for a given reservoir comprised five main objectives: (1) generate reservoir surface area time series; (2) generate surface elevation time series; (3) build and apply a linear regression model relating surface area and elevation; (4) estimate volumetric change over the study period; and (5) assess agreement between modeled and in situ volumes.

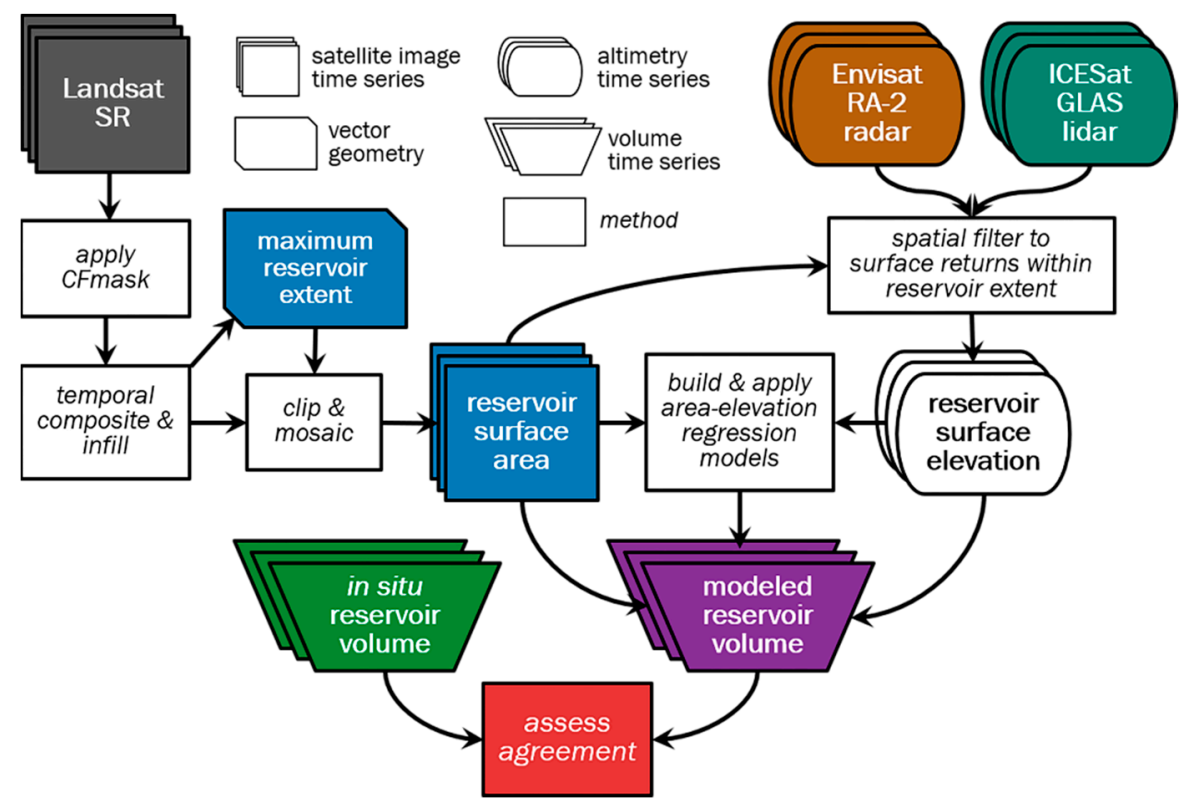

Figure 3. Overview of analytical framework to generate surface area, elevation, and volumetric time series for a given reservoir. Colors shown for each dataset are consistent throughout all figures.

\subsection{Surface Area Time Series Generation}

The 13 study reservoirs collectively span 15 Landsat WRS-2 path-row footprints, with three reservoirs stretching across $2-4$ footprints, respectively. A total of 1460 Landsat 5,7 , and 8 surface reflectance (SR)-corrected scenes with $20 \%$ or less cloud cover were collected from 2003 through 2014; this cloud cover threshold reduced the likelihood of missing data due to cloud cover while still supporting an intra-annually dense time series. We measured surface water time series with the commonly used Modified Normalized Difference Water Index (MNDWI), which is effective at discriminating water from non-water features [57]. We included all pixels that have a MDWI value larger than 0.1 as 'water' for each image date. Missing pixels associated with clouds, shadows, and Landsat 7's Scan Line Corrector (SLC) Error data gaps were identified and removed using Landsat's CFmask product. For each image's missing pixels, pixels from images collected within a 36-day window before/after (e.g., Figure $4 \mathrm{a}-\mathrm{c}$ ) were infilled into the image, prioritized by the nearest date of observation (e.g., Figure 4d). Infilling using a 36-day temporal window ensured inclusion of images from up to two along-track (every 16 days) and up to four across-track ( 7 or 9 days) observations and reduced the amount of missing data within an average reservoir from $8.6 \%$ to $1.2 \%$ (Figure 5). On some dates, an image's missing pixels could not be directly infilled through temporal compositing; in this case, if these missing pixels were in locations classified as 'water' on at least the median frequency for a given reservoir, the missing pixels were automatically included in the surface water extent. A reservoir's water frequency map showing the total number of days when 'water' was detected (Figure 4e) was also used to generate a consistent spatial extent within which surface water area was measured: pixels classified as 'water' on at least two dates made up an 'ever-water' envelope for this purpose (shown in Figure 4). Finally, each reservoir's surface area time series was clipped by an integrated (i.e., upstream to dam wall) reservoir region that was visually interpreted using very high-resolution imagery hosted by Google Earth. 


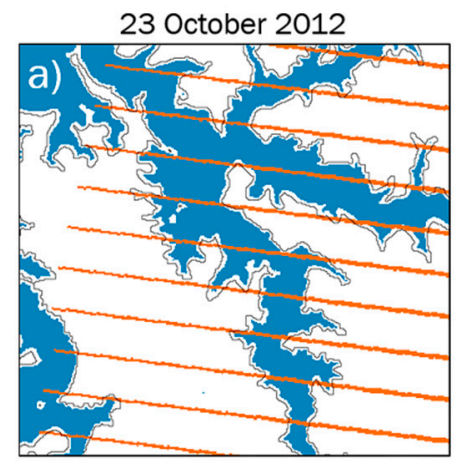

infilled 8 November 2012

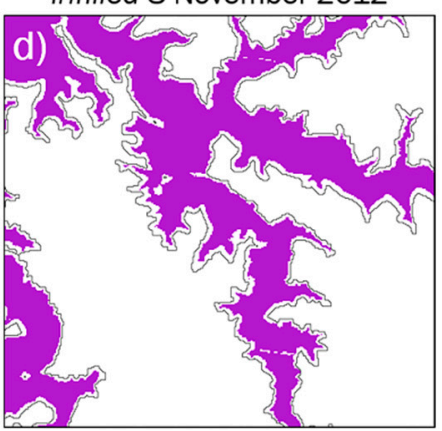

8 November 2012

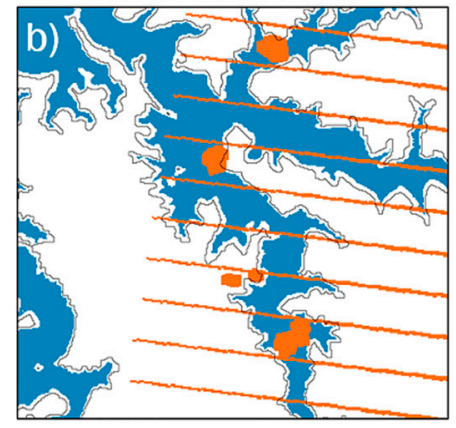

2003-2014 water frequency

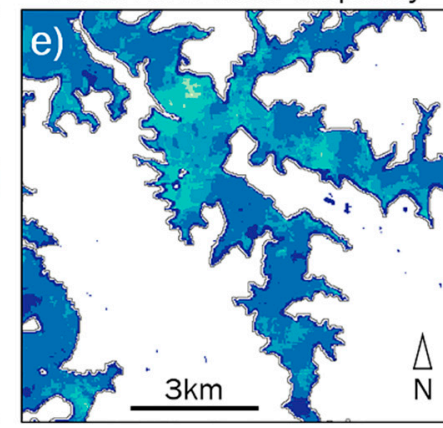

24 November 2012



reservoir water extent

clouds/shadow/SLC-off

ever-water envelope

$>84$

dates with water detected

74

Figure 4. Example generation of temporally composited, infilled surface water extent maps showing southeastern Chavantes reservoir. (a-c) Surface water coverage from three near-date images (23 October, 8 November, and 24 November 2012) with data gaps. (d) Coverage maps are composited to create an infilled surface water map for 8 November 2012. (e) A time series of infilled water maps are used to generate a water frequency map for 2003-2014.

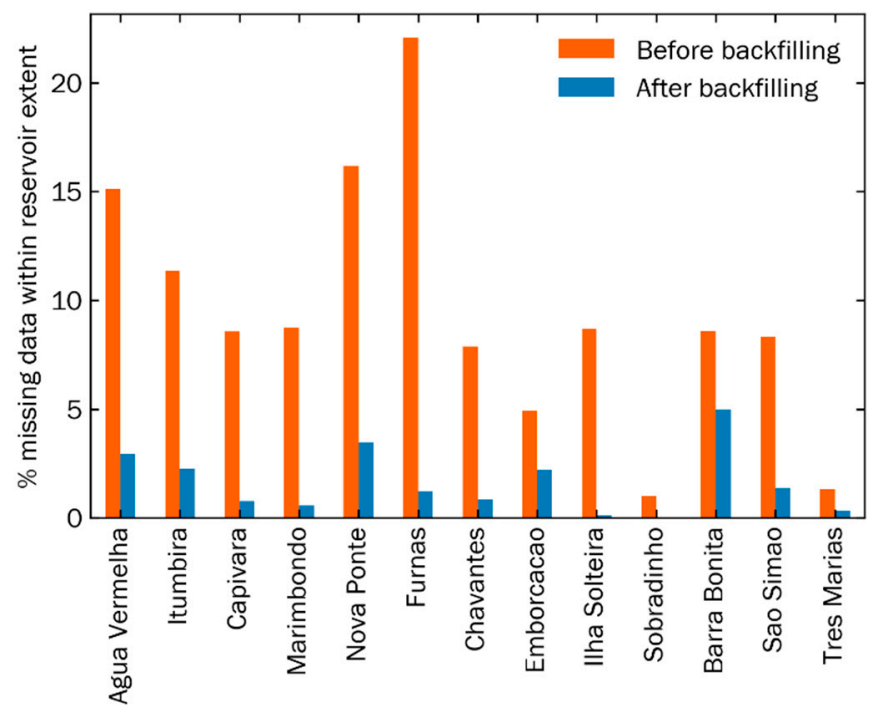

Figure 5. Reductions in average percentage of missing data across all image dates and reservoirs after infilling.

\subsection{Surface Elevation Time Series Generation}

Separate surface water elevation time series were built using Envisat RA-2 (2002-2010) and ICESat GLAS (2003-2009) altimetry data, respectively. The long wavelength of Envisat's RA-2 (Ku-band) radar altimetry provides resilience to cloud cover effects while the vertical profiling capabilities of ICESat's GLAS support the discrimination of ground-level conditions in all but the densest cloud cover [31,58]. Both RA-2 and GLAS datasets are suitable for reservoir monitoring with along-track 
sampling distances of approximately 350 and $172 \mathrm{~m}$, nominal footprint sizes of approximately $2 \mathrm{~km}$ and $70 \mathrm{~m}$, and vertical accuracies (i.e., RMSE) of approximately 50 and $15 \mathrm{~cm}$ [59], respectively. Envisat altimetry has often been used for measuring freshwater surface elevation changes (e.g., [60-67] though ICESat has been used less often for monitoring surface water dynamics due to its erratic operational history of premature laser failures see [68] with notable exceptions (e.g., [69-73]).

The Envisat RA-2 surface elevation time series was generated using an automated return clustering algorithm detailed in [74], which yielded an average RMSE of $48.9 \mathrm{~cm}$ compared to in situ gauge observation data across study reservoirs. ICESat GLAS GLA14 product (Level-2 Global Land Surface Altimetry; [75]) data were filtered to single Gaussian peak returns typical of surface water, saturated returns were corrected or removed using the saturation index, and surface elevation was calculated at the centroid of the single Gaussian peak. All RA-2 and GLAS surface returns collected within 15 days of a Landsat surface area measurement were spatially filtered by the surface area perimeter buffered inwards by $100 \mathrm{~m}$ to eliminate potential measurement of near-surface topography. The median elevation over a reservoir's extent on a given date was measured and used to generate reservoir elevation and volume time series. Since GLAS' reference ellipsoid (equatorial radius $=6378.1363 \mathrm{~km}$; flattening coefficient $=1 / 298.257$ ) is offset $70 \mathrm{~cm}$ from RA-2's WGS 84 ellipsoid, GLAS elevation data were adjusted to fit the WGS 84 vertical datum following [76].

\subsection{Surface Area-Elevation Model Generation}

Surface area and elevation time series were used to estimate changes in reservoir volumes. However, since the vast majority of surface area measurements lacked same-day measurements of surface elevation, regression models were built for each reservoir to relate surface area measurements to altimeter elevations collected within 15 days of the surface area measurement; linear regression was used following successful regional application (e.g., [23,25,49]). Modeled surface elevation values based on measured surface areas were used to build an elevation time series with the same temporal sampling as the surface area time series. The goodness-of-fit of each reservoir's area-elevation model was measured using the Pearson correlation coefficient (r) and the root mean square error (RMSE).

\subsection{Volume Time Series Generation}

As the volume of a reservoir with unknown bathymetry cannot be remotely measured, the reservoir was rather conceived as a circular cone with a series of water layers as detailed in [77]. Reservoir volume on a given date, $t$, was based on changes in surface area and elevation time series data measured relative to the median 2003-2011 volume (before the drought):

$$
V_{\text {med }-t}=\frac{1}{3}\left(z_{t}-z_{\text {med }}\right) *\left(A_{\text {med }}+A_{t}+\sqrt{\left(A_{\text {med }} * A_{t}\right)}\right)
$$

where, $V_{\text {med- } t}$ represents the relative difference in volume, $A_{\text {med }}$ and $A_{t}$ and $z_{\text {med }}$ and $z_{t}$ represent surface areas and elevations based on median 2003-2011 values and the date of observation, respectively. The median 2003-2011 in situ volume was measured for each reservoir to serve as a pre-drought baseline, and the relative volume difference for each date of in situ observation was measured.

\subsection{Comparison between In Situ and Modeled Volumetric Time Series}

Changes in modeled reservoir volumes were compared to a median 4383 daily in situ reservoir volume measurements collected from 2003-2014 by the Brazilian Electric Sector available at http: / / www.ons.org.br/. However, study reservoir boundaries deviated from (unavailable) management boundaries used by the Brazilian Electric Sector to collect in situ volume and modeled and in situ 
volume time series could not be directly compared. To mitigate this disparity, both time series were standardized to preserve relative variations with the following equation:

$$
S_{t}=\frac{\left(V_{t}-\bar{V}\right)}{\sigma}
$$

where $S_{t}$ and $V_{t}$ are standardized and modeled volume changes for a given reservoir on date, $t$, respectively, and $\bar{V}$ and $\sigma$ are the mean and standard deviation of modeled volume changes over the full time series, respectively. Using standardized (unitless) values, the agreement between modeled and in situ volume dynamics time series were assessed using linear regression, $r$, and RMSE, and annual and monthly agreement between modeled and in situ data were evaluated.

\section{Results}

\subsection{Surface Area and Elevation Time Series}

Over the 12-year study period, a median 216 Landsat image dates were used to generate each reservoir surface area time series (Figures 6 and A1). Prior to the drought's intensification in 2014, reservoirs typically reached their lowest extent in December or January before recharging to the maximum surface area between March and June following the end of the rainy season. Surface water expansion and contraction was highly dynamic with a median annual range (i.e., difference between maximum and minimum) of reservoir surface areas representing $31.3 \%$ of the maximum surface area in the pre-drought 2003-2011 period. During the drought period (2012-2014), this range was nominally consistent at $30.7 \%$ though the minimum and maximum surface areas declined relative to the pre-drought period by median $4.5 \%$ and $3.6 \%$, respectively. Seasonal dynamics shifted under the drought, as well, as early year recharge was typically reduced in 2012 and 2013 and absent by 2014. Reservoirs such as Furnas and Tres Marias contracted during the drought so much that low surface areas (below $900 \mathrm{~km}^{2}$ and $350 \mathrm{~km}^{2}$, respectively) were without precedent in the pre-drought time series.


Figure 6. Landsat-derived surface area time series for four reservoirs with dates of ICESat GLAS (green dot) and Envisat RA-2 (red dot) measurement. The gray background indicates the range of surface areas measured on altimetry data collection dates. Time series for all 13 reservoirs are shown in Figure A1. 
While each reservoir's seasonal dynamics are apparent, there was often a disproportionate exclusion of cloudy wet season imagery (October-March; Figures 7a and A2). Conversely, since cloud-free observations are more likely in eastern Brazil during winter months, there is a relative abundance of imagery available in July and August when reservoirs tend to be near capacity. Fewer images and generally more cloud cover during the wet season meant fewer near-date images for infilling and compositing, which may yield a larger amount of residual missing data and low biased surface area estimates [33], as well as fewer surface area measurements with which to couple elevation data. While the collection of surface elevation values was not affected by atmospheric conditions in the same way as surface area measurements, having a larger surface area (unobstructed by clouds) meant that more altimetric returns could be collected over the reservoir body (Figures $7 \mathrm{~b}$ and A3).

a)
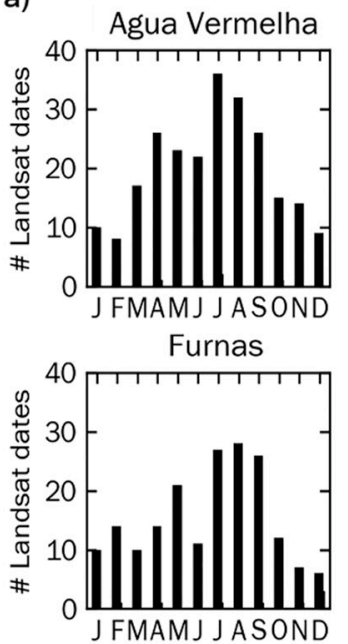
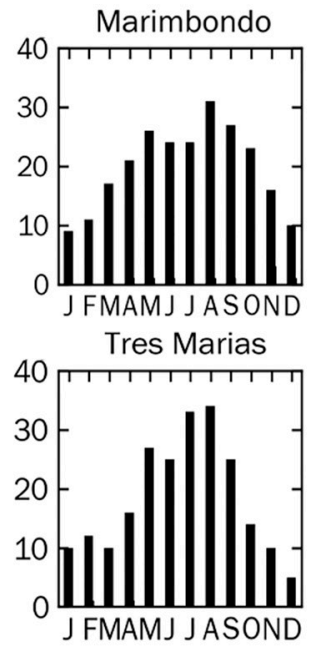

b)
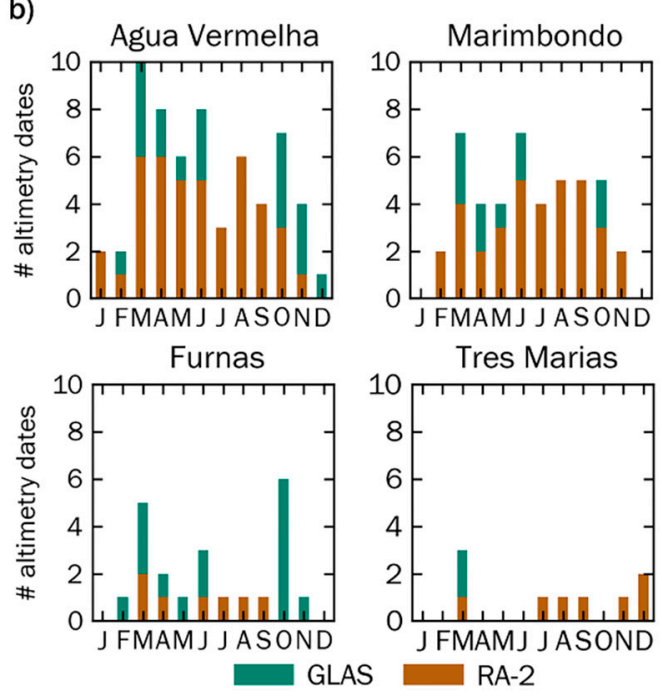

Figure 7. Monthly frequency of (a) Landsat images and (b) GLAS and RA-2 surface elevation observations for four selected reservoirs from 2003-2014. Monthly frequency of Landsat images and surface elevation observations for all 13 reservoirs are shown in Figures A2 and A3, respectively.

\subsection{Modeled Surface Area-Elevation Relationships}

Linear regression models relating Landsat-derived surface area and altimeter-derived surface elevation measurements were built for the 13 study reservoirs (Figures 8 and A4). The median number of area-elevation pairs for "combined" regression models was 21, with 13 and 17 measurements for GLAS- and RA-2-specific models, respectively. Combined linear models showed high goodness-of-fit with a median RMSE of $0.89 \mathrm{~m}$ and $\mathrm{r}$ of 0.88 across reservoirs. A poor model may reflect a combination of seasonal variation in surface area and elevation, differences in Landsat and altimetry acquisition dates, variation in bathymetric slope along a reservoir's perimeter and across its depth, as well as lingering cloud cover effects. Though GLAS and RA-2 elevations span a median 74.9\% of reservoir surface area range (highlighted in grey in Figures 6 and A1), the elevation distribution is often skewed towards including higher elevations. This skew is most pronounced for reservoirs with fewer dates of observation during the wet season as well as those with a smaller surface area, which limits the area within which altimetry data could be collected. The contraction of surface areas during the drought also limited potential for coupling surface area-elevation values as very low surface areas during the drought had no paired elevation values. 


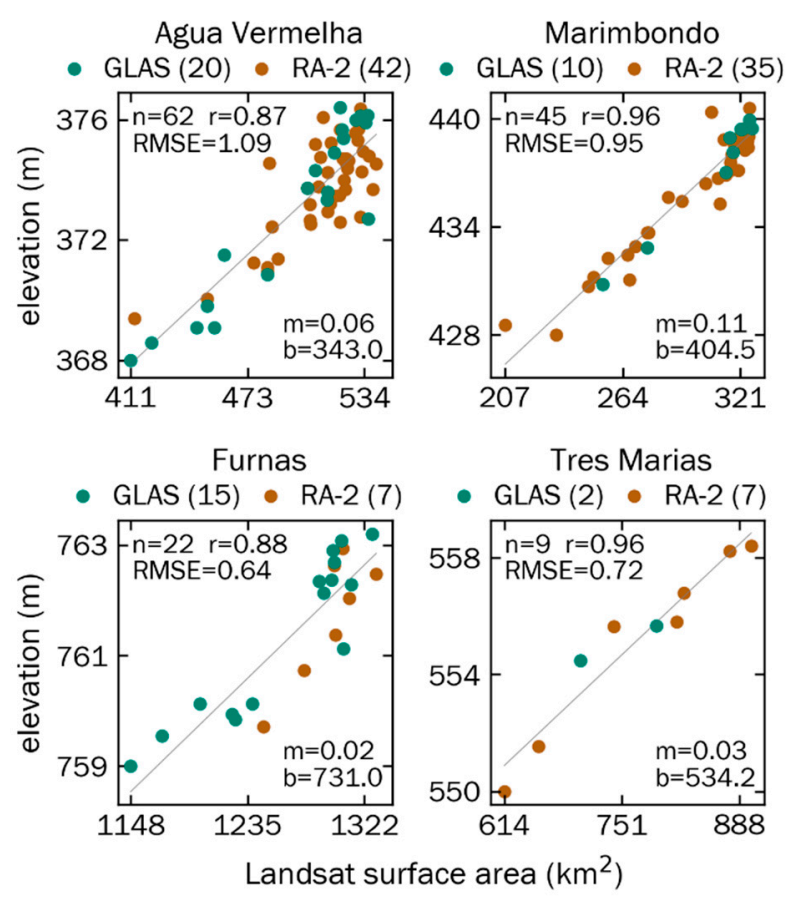

Figure 8. Derived surface area-elevation linear regressions for four selected reservoirs based on Landsat surface area and combined GLAS and RA-2 elevation data. $n=$ number of area-elevation pairs, $\mathrm{r}=$ Pearson correlation coefficient, RMSE = root mean square error, $\mathrm{m}=$ linear slope, $\mathrm{and} \mathrm{b}=$ linear intercept. Area-elevation models for all 13 reservoirs are in Figure A4.

GLAS-specific models provided a slightly better fit with median RMSE $=0.68 \mathrm{~m}$ and $\mathrm{r}=0.94$ compared to RA-2's RMSE $=0.94 \mathrm{~m}$ and $\mathrm{r}=0.90$ (see Table A1). The better fit provided by GLAS is expected given its higher vertical accuracy and smaller footprint. For the 8 of 11 reservoirs with both GLAS and RA-2 coverage over the study period, GLAS also captured a larger surface area range despite GLAS having fewer samples for these reservoirs (see Figure A4). Further, GLAS alone provided coverage for two reservoirs, Ilha Solteira and Sao Simao. Despite the driving role of GLAS data in shaping surface area-elevation models, there remains considerable value in combining altimeter measurements into a single area-elevation model. Since GLAS and RA-2 captured reservoirs at different stages over the time series, combining altimetric observations in a single model expanded the seasonality of coverage, which helped compensate for irregularity of observations at a given reservoir. Combining altimetric data also increased the average range of observed surface elevations across reservoirs by at least $1.3 \mathrm{~m}$ compared to the elevation range observed by either GLAS or RA-2 alone. This expanded range supports characterizing reservoir dynamics from the drawdown through recharge conditions, which is especially valuable for reservoirs with a large annual range, e.g., Agua Vermelha. 3.3. Volume Time Series and In Situ Comparison.

Across reservoirs, the median modeled volume time series is composed of 216 time steps (Figures $9 \mathrm{a}$ and $\mathrm{A} 5 \mathrm{a}$ ). Of these, $88 \%$ of time series values were based on reservoir-specific surface area-elevation regression models (i.e., Figure 8) while the remaining $12 \%$ were based on direct observations. While some reservoirs such as Agua Vermelha have a clear, consistent seasonality with a pronounced annual recharge and depletion, other reservoirs such as Chavantes or Sao Simao (see Figure A5) are much less dynamic. Linear regression models showed exceptionally high agreement between modeled and in situ volumetric changes with median RMSE $=0.31 \mathrm{~km}^{3}$ and $\mathrm{r}=0.95$ (Figure $9 \mathrm{~b}$ ). The low median bias of $0.11 \mathrm{~km}^{3}$ indicates an underestimation of in situ volume, and, indeed, each reservoir's maximum modeled volume was consistently less than the maximum in situ volume. This divergence likely results from the mismatch between reservoir boundaries used to generate 
modeled values and boundaries considered in in situ data collection, differing 2003-2011 reference volumes, and spuriously low modeled volumes that most often occur during the wet season.

a)
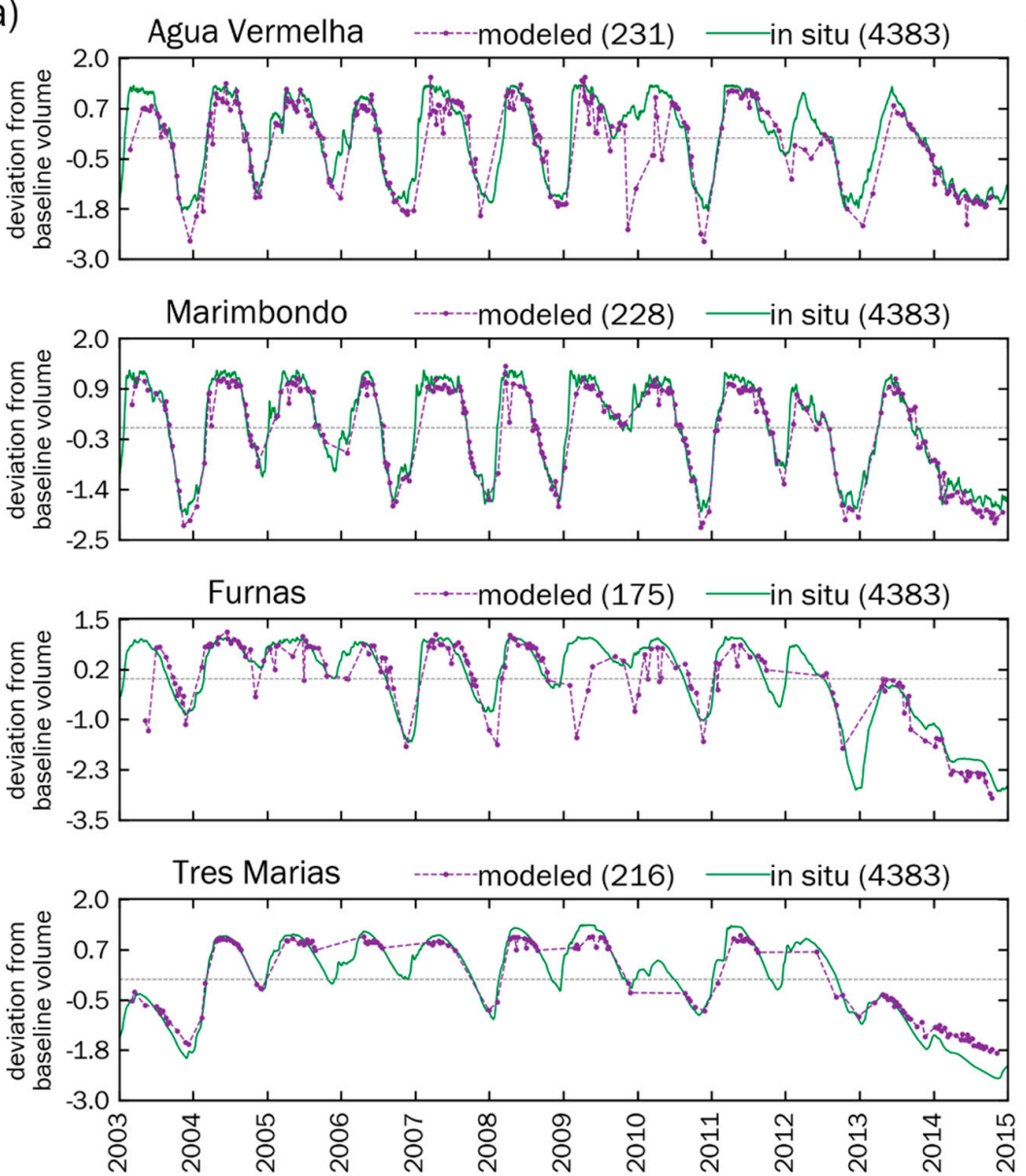

b)


Figure 9. (a) Time series of difference between standardized reservoir volumes and each reservoir's baseline, pre-drought (i.e., median 2003-2011) volume for modeled (purple) and in situ (green) data, respectively; for dates without altimetry data, regression-based elevation values are used in modeling volume. (b) Linear regressions relating standardized in situ and modeled volumes on dates of mutual observation. Light grey lines in (a) and (b) indicate zero values on respective axes. All volume values are in $\mathrm{km}^{3}$. Time series and regressions for all 13 reservoirs are in Figure A5.

To examine intra-annual variation in agreement, the mean absolute difference between modeled and in situ volumetric change was estimated for each month (Figures 10 and A6). Wet season months (October-March) showed higher disagreement than winter months (July-August) in 5 of 13 study reservoirs. Since reservoirs tend to have their lowest volumes during wet months of November-January, accurately modeling reservoir volumes during these low volume months would improve modeling of anomalously low volumes during drought periods. Considering inter-annual variation, the mean annual flux (i.e., the range of standardized volumes within a calendar year) of modeled and in situ time series only differed between 0.004 and 0.041 in 2003-2010 across reservoirs (Figure 11). With the drought came a larger disagreement of 0.62 in 2012 but was reduced to a very low disagreement of only 0.04 in 2014. The divergence between modeled and in situ flux in 2011-2013 was likely influenced by fewer Landsat images being collected after Landsat 5 operational imaging ended in November 2011, 17 months before Landsat 8's operational imaging began in April 2013. The agreement in 2014 benefitted from Landsat 8's data collection, a low annual flux due to the drought, and good 
fitting area-elevation regression models that allowed for estimating elevations beyond the range of historical direct observation.
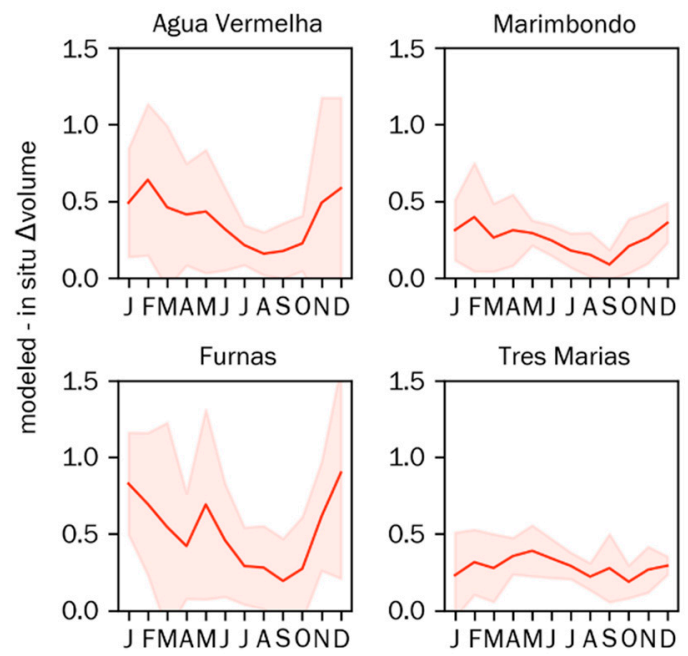

Figure 10. Mean monthly absolute difference between modeled and in situ standardized (unitless) volume changes (2003-2014; red line) with standard deviation range (red field). Monthly comparisons for all 13 reservoirs are in Figure A6.

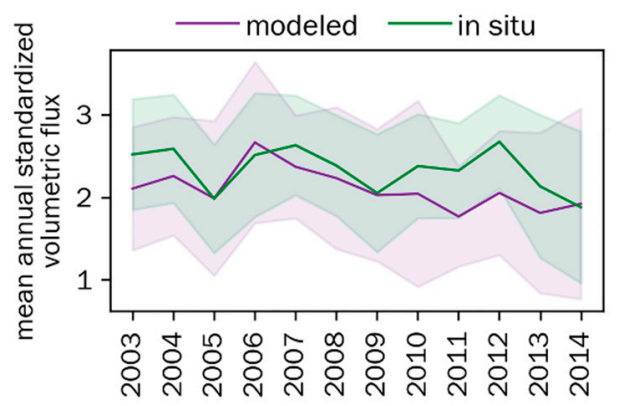

Figure 11. Comparison between mean annual flux of standardized (unitless) modeled (purple line) and in situ (green line) volume dynamics across all study reservoirs with \pm 1 standard deviation ranges (purple and green fields, respectively).

\section{Discussion}

Accurate long-term monitoring of reservoir dynamics achieved by this study is of paramount interest for assessing United Nations Development Program Sustainable Development Goal (SDG) 6 (Clean Water and Sanitation) and 7 (Affordable and Clean Energy) [78], managing national-level water resources, examining reservoir dynamics and hydroelectric power generation (e.g., [3]), assessing the impact of changing precipitation and temperature regimes on reservoir storage $[54,56,79,80]$, and as input to or validation of hydrodynamic models (e.g., [81-83]. This study's high agreement between remote sensing and in situ volumetric flux (i.e., RMSE $=0.31 \mathrm{~km}^{3}$ ) illustrates the potential for effective monitoring in tropical regions with persistent cloud cover or even those affected by historic drought.

Volumetric modeling is an essential tool in monitoring climate effects on global surface water dynamics especially in regions with unavailable or scarce in situ data [43]. This study builds on research by $[19,20,22-25,65,84,85]$ in pursuing remote sensing-based estimation of reservoir volume dynamics. However, this research alongside [49] extends previous efforts by maintaining high accuracy in modeled volume changes outside the historical range of altimetric observations, in this case due to historic drought. Though the drought began in 2012, the reduction of reservoir surface areas, elevations, and volumes was broadly delayed across study reservoirs until 2013 as is evident in modeled and in situ volumetric change time series (e.g., Figure A5). In 2013, surface elevations at eight of the study 
reservoirs fell below the observed minimum surface elevation from 2000-2009; by 2014, 12 of the 13 study reservoirs had done so. Despite extrapolating surface area-elevation relationships to capture volumetric change in 2013-2014, the mean standardized modeled and in situ volumetric fluxes (e.g., Figure 11) were in agreement, thereby demonstrating the effectiveness of monitoring. Volume estimate accuracies for Tres Marias, Marimbondo, and others are comparable to those achieved by [19] (i.e., $r=0.99$ ) despite this study's challenges of persistent cloud cover and extreme volumetric loss.

Limited observational frequency remained a challenge in this study. The largest difference between mean annual standardized modeled and in situ volumetric fluxes was 0.62 (unitless) and measured in 2012. This did not result from drought-induced depletion but was rather associated with reduced surface area measurements since only Landsat 7 was operational in 2012. Nonetheless, despite intra-annual variability of surface area measurements, limited observational data, and drought-induced depletion of reservoir volume beyond the range of observations, agreement between modeled and in situ volume dynamics was high. This is perhaps best exemplified by Tres Marias, which lacked any altimetry observations for six months of the calendar year yet shows better agreement with in situ volume data (i.e., RMSE $=0.14 \mathrm{~km}^{3}$ ) than any other reservoir. Future volumetric modeling efforts will benefit from the increased observational frequency by including additional surface area time series from Sentinel-1, Sentinel-2, as well as the upcoming Surface Water and Ocean Topography (SWOT) mission [86]. Similarly, while no current hydrodynamic models accurately simulates reservoirs and lakes, recent developments on hydrological modeling have taken into account reservoir operation (e.g., [87-89]). Results presented in this study can therefore be used for further model evaluation and improvement of model parameters to better model human activities.

Errors inherent to the volumetric modeling approach include Landsat-derived surface area resolution, altimetry-derived vertical resolution, area-elevation linear regression modeling, and unavailable reservoir boundaries used for in situ data collection. Moreover, referencing the median water frequency coverage for infilling remaining pixels that could not be directly infilled with temporal compositing lead to overestimating surface area and volume on low volume days and underestimating surface area and volume on high volume days; this, in turn, degraded surface area-elevation correlations. While a linear area-elevation relationship that assumes a consistent bathymetric (i.e., hypsographic) profile across all depths and along the entire boundary of a given shoreline has been used effectively by other researchers (e.g., [23]), non-linear models have also been used to model sections or the entirety of a reservoir's hypsographic profile (e.g., [36,85]). A more extensive examination of the relationship between reservoir dynamics and bathymetry would have added valuable information. Unfortunately, there were no available reference bathymetry datasets with which to evaluate this relationship, nor were there surface area validation time series data with which to evaluate the accuracy of surface area dynamics for any reservoir in the study. Including information from a high-resolution bathymetric model would have improved volumetric modeling effort [84].

There are several opportunities for improving the water classification through use of a more advanced classification approach sensitive to reservoir-specific hydrologic conditions such as clarity, turbidity, and bathymetry, e.g., [90]. The results of this study point towards more effective monitoring using recently launched sensors such as Sentinel 1 and 2 [91-93]. The use of $20 \mathrm{~m}$ spatial resolution Sentinel 2A and 2B time series data with a nominal 5-day temporal resolution rather than $30 \mathrm{~m}$, 16-day repeat Landsat data have the potential to estimate much more detailed volumetric changes, especially for reservoirs with complex shorelines that cannot be readily captured with Landsat, let alone MODIS imagery. Use of imaging radars such Sentinel 1, SWOT, and RADARSAT-2 [94] with $<100$ m horizontal resolution and $<10 \mathrm{~cm}$ vertical resolution as well as passive microwave sensors [95] offer data fusion opportunities that make the most of available optical and passive time series data. 


\section{Conclusions}

This study presented a remote sensing-based approach for monitoring reservoir dynamics over a 12-year period (2003-2014), which included a historic two-year long drought. Using the case study of regularly clouded eastern Brazil, Landsat 5, 7, 8, ICESat GLAS, and Envisat RA-2 time series data were used to measure surface area, elevation, and volume time series for 13 study reservoirs of varying size and intra- and inter-annual dynamics. Volumetric changes have high overall agreement with in situ volumetric time series data as well as intra- and inter-annual agreement throughout the study period including the drought. The high agreement despite regular cloud obfuscation and drought depletion points the way towards routine, very high-resolution monitoring of reservoir dynamics in regions that lack existing or available in situ monitoring. While this study benefits from reservoir management data, anticipated applications extend to regularly clouded regions without existing or otherwise inaccessible data on reservoir dynamics.

Author Contributions: Conceptualization, J.V.D.H., A.G., and H.C.J.; Formal analysis, J.V.D.H., M.O., and H.L.; Methodology, J.V.D.H., A.G., and H.C.J.; Visualization, J.V.D.H.; Writing—original draft, J.V.D.H.; Writing一review \& editing, J.V.D.H.

Funding: This research received no external funding.

Conflicts of Interest: The authors declare no conflict of interest.

\section{Appendix A}
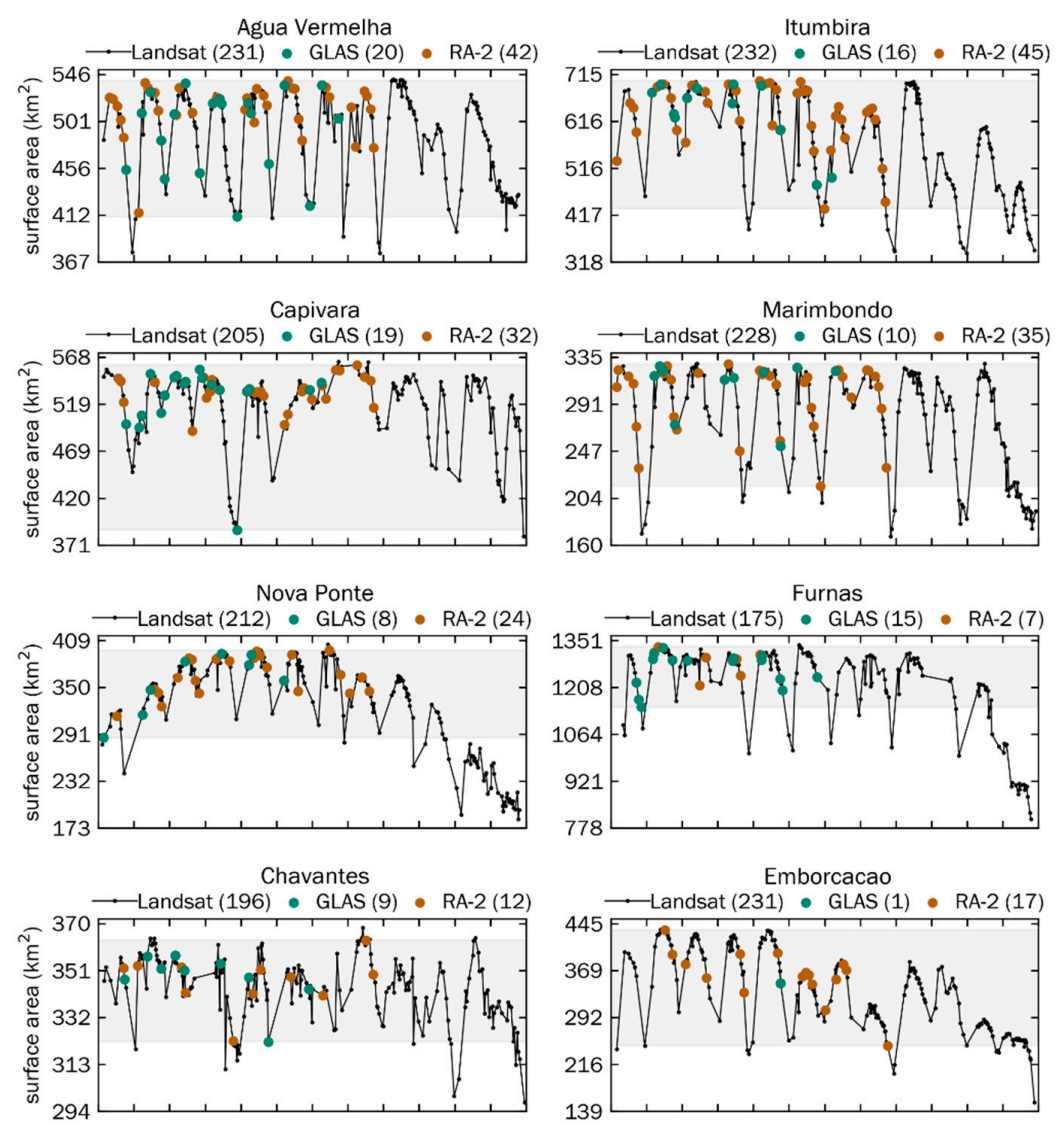

Figure A1. Cont. 

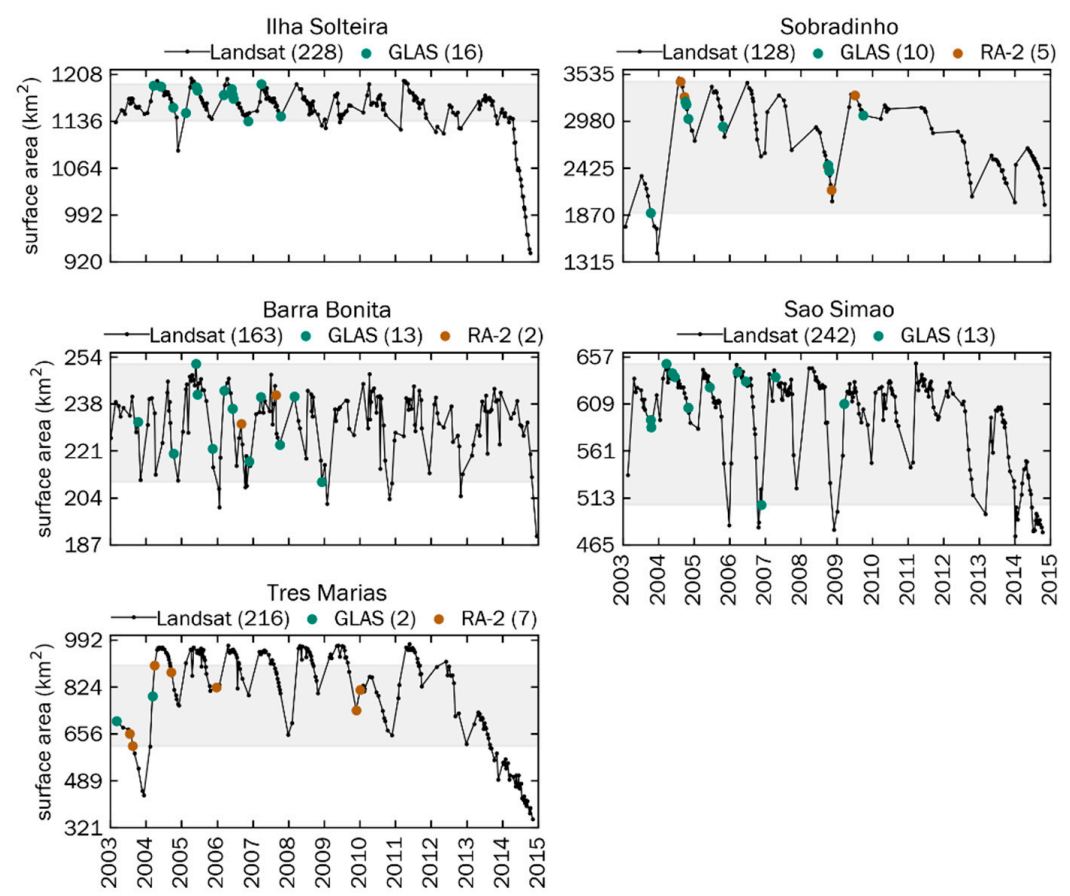

Figure A1. Landsat-derived surface area time series for all 13 study reservoirs with dates of ICESat GLAS (green dot) and Envisat RA-2 (red dot) measurement. The gray background indicates the range of surface areas measured on altimetry data collection dates. Time series for select four reservoirs are shown in Figure 6.
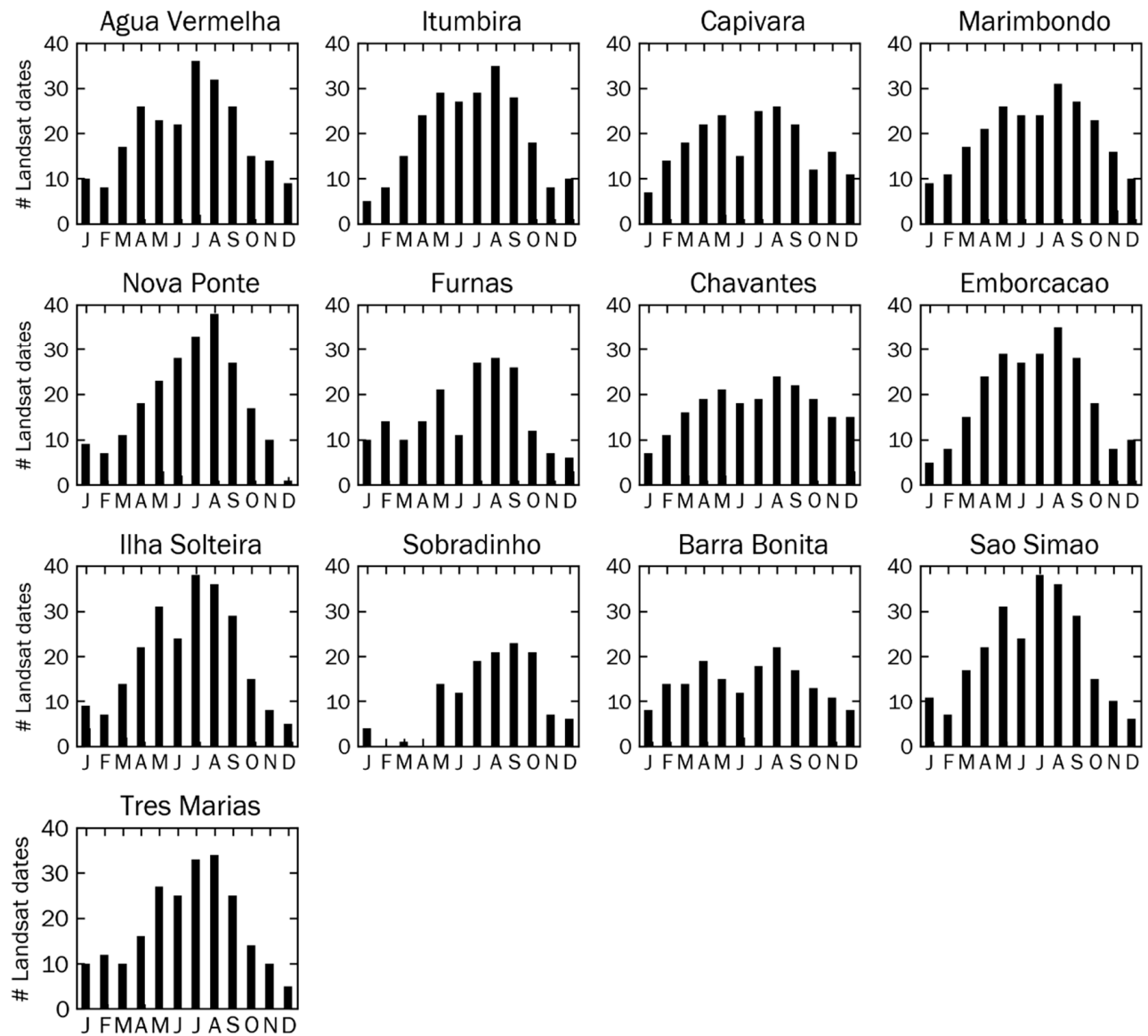

Figure A2. Stacked monthly frequency of Landsat images for all 13 study reservoirs. Monthly frequency information for four selected reservoirs is in Figure 7. 

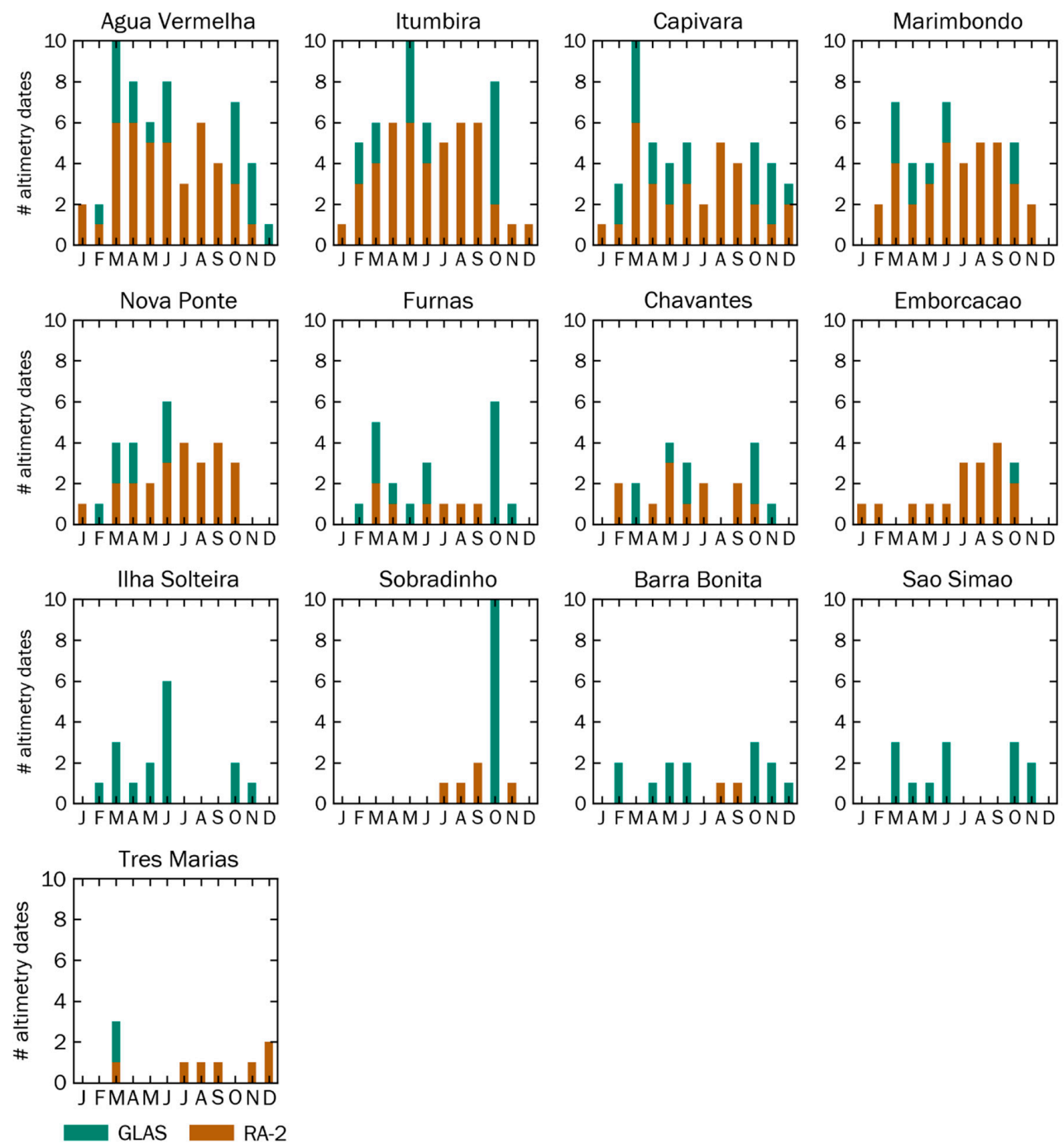

Figure A3. Stacked monthly frequency of GLAS and RA-2 surface elevation observations for all 13 study reservoirs. Monthly frequency information for four selected reservoirs is in Figure 7. 



- GLAS (15) - RA-2 (7)

- GLAS (9) - RA-2 (12)
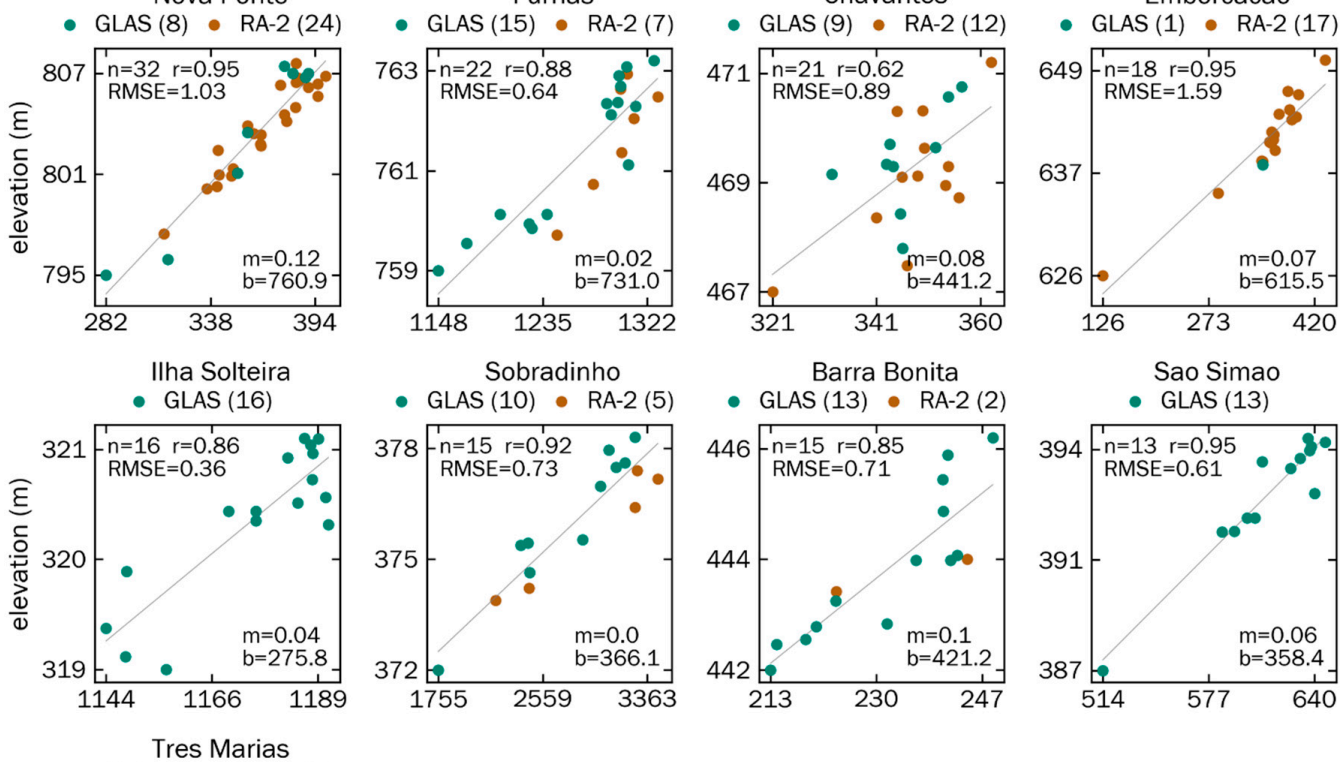

- GLAS (10) - RA-2 (5)
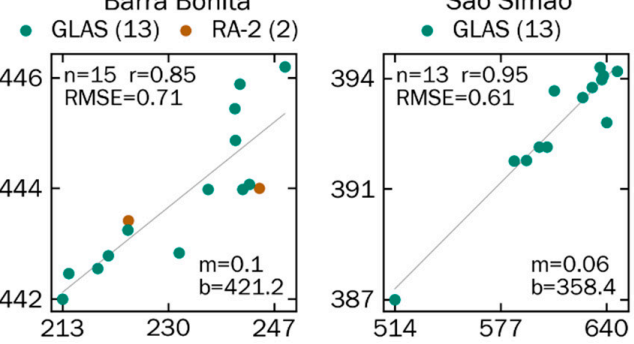

- GLAS (2) - RA-2 (7)
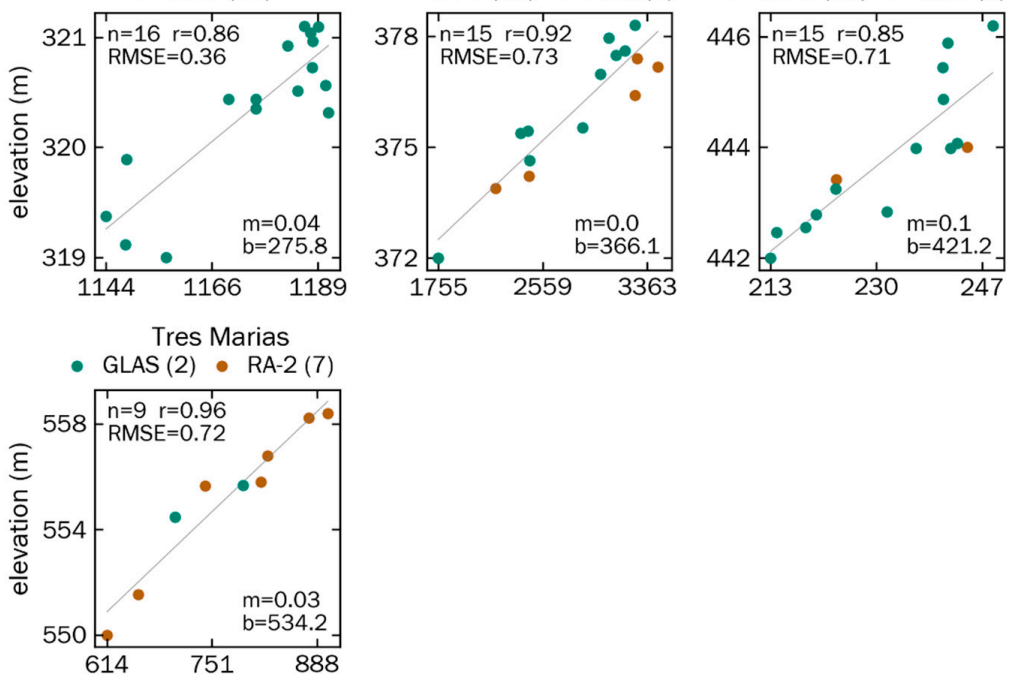

Landsat surface area $\left(\mathrm{km}^{2}\right)$

Figure A4. Derived surface area-elevation linear regressions for all 13 study reservoirs based on Landsat surface area and combined GLAS and RA-2 elevation data. $\mathrm{n}=$ number of area-elevation pairs, $\mathrm{r}=$ Pearson correlation coefficient, RMSE = root mean square error, $\mathrm{m}=$ linear slope, and $\mathrm{b}=$ linear intercept. Area-elevation models for select four reservoirs are in Figure 8. 
Table A1. List of reservoir-specific linear regression model parameters and goodness-of-fit values for GLAS- or RA-2-specific models as well as 'combined' models. $\mathrm{n}=$ number of altimeter surface elevation measurements, $\mathrm{m}=$ linear slope, $\mathrm{b}=$ linear intercept, $\mathrm{r}=$ Pearson correlation coefficient, and RMSE = root mean square error.

\begin{tabular}{|c|c|c|c|c|c|c|}
\hline Reservoir Name & Altimeter & $\mathbf{n}$ & m & $\mathbf{b}$ & $\mathbf{r}$ & RMSE \\
\hline \multirow{3}{*}{ Agua Vermelha } & GLAS & 20 & 0.070 & 339.10 & 0.933 & 1.054 \\
\hline & RA-2 & 42 & 0.054 & 347.03 & 0.777 & 1.055 \\
\hline & combined & 62 & 0.062 & 343.01 & 0.867 & 1.088 \\
\hline \multirow{3}{*}{ Barra Bonita } & GLAS & 13 & 0.109 & 419.13 & 0.884 & 0.683 \\
\hline & RA-2 & 2 & 0.097 & 422.63 & 0.839 & 0.745 \\
\hline & combined & 15 & 0.100 & 421.21 & 0.855 & 0.710 \\
\hline \multirow{3}{*}{ Capivara } & GLAS & 19 & 0.063 & 295.13 & 0.937 & 0.864 \\
\hline & RA-2 & 32 & 0.075 & 288.46 & 0.773 & 0.979 \\
\hline & combined & 51 & 0.064 & 294.41 & 0.862 & 0.982 \\
\hline \multirow{3}{*}{ Chavantes } & GLAS & 9 & 0.077 & 443.26 & 0.548 & 0.799 \\
\hline & RA-2 & 12 & 0.087 & 439.30 & 0.681 & 0.902 \\
\hline & combined & 21 & 0.082 & 441.21 & 0.622 & 0.887 \\
\hline \multirow{3}{*}{ Emborcacao } & GLAS & 0 & - & - & - & - \\
\hline & RA-2 & 17 & 0.074 & 615.69 & 0.951 & 1.534 \\
\hline & combined & 17 & 0.074 & 615.69 & 0.951 & 1.534 \\
\hline \multirow{3}{*}{ Furnas } & GLAS & 15 & 0.024 & 730.67 & 0.921 & 0.567 \\
\hline & RA-2 & 7 & 0.038 & 712.25 & 0.863 & 0.559 \\
\hline & combined & 22 & 0.024 & 731.00 & 0.883 & 0.641 \\
\hline \multirow{3}{*}{ Ilha Solteira } & GLAS & 16 & 0.039 & 275.78 & 0.863 & 0.362 \\
\hline & RA-2 & 0 & - & - & - & - \\
\hline & combined & 16 & 0.039 & 275.78 & 0.863 & 0.362 \\
\hline \multirow{3}{*}{ Itumbira } & GLAS & 16 & 0.054 & 471.90 & 0.977 & 0.861 \\
\hline & $\mathrm{RA}-2$ & 45 & 0.045 & 478.62 & 0.840 & 1.994 \\
\hline & combined & 61 & 0.048 & 476.73 & 0.872 & 1.869 \\
\hline \multirow{3}{*}{ Marimbondo } & GLAS & 10 & 0.127 & 398.20 & 0.985 & 0.504 \\
\hline & $\mathrm{RA}-2$ & 35 & 0.102 & 405.62 & 0.954 & 0.995 \\
\hline & combined & 45 & 0.106 & 404.51 & 0.958 & 0.947 \\
\hline \multirow{3}{*}{ Nova Ponte } & GLAS & 8 & 0.129 & 757.66 & 0.968 & 1.210 \\
\hline & $\mathrm{RA}-2$ & 24 & 0.113 & 762.89 & 0.942 & 0.887 \\
\hline & combined & 32 & 0.119 & 760.86 & 0.952 & 1.028 \\
\hline \multirow{3}{*}{ Sao Simao } & GLAS & 13 & 0.057 & 358.41 & 0.955 & 0.612 \\
\hline & $\mathrm{RA}-2$ & 0 & - & - & - & - \\
\hline & combined & 13 & 0.057 & 358.41 & 0.955 & 0.612 \\
\hline \multirow{3}{*}{ Sobradinho } & GLAS & 10 & 0.004 & 364.81 & 0.963 & 0.544 \\
\hline & RA-2 & 5 & 0.003 & 367.01 & 0.974 & 0.370 \\
\hline & combined & 15 & 0.004 & 366.13 & 0.925 & 0.729 \\
\hline \multirow{3}{*}{ Tres Marias } & GLAS & 2 & 0.029 & 535.31 & 0.963 & 0.743 \\
\hline & RA-2 & 7 & 0.029 & 533.10 & 0.977 & 0.658 \\
\hline & combined & 9 & 0.028 & 534.18 & 0.964 & 0.719 \\
\hline
\end{tabular}


a)
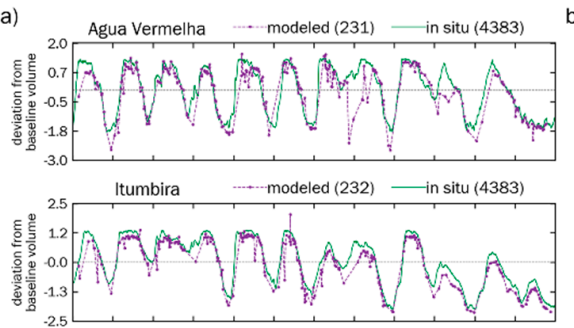

Capivara



Marimbondo --.--modeled (228) —in situ (4383)

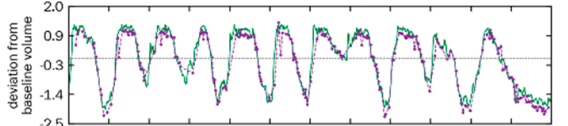

Nova Ponte $\quad-\cdots-$ - modeled (212) — in situ (4383)
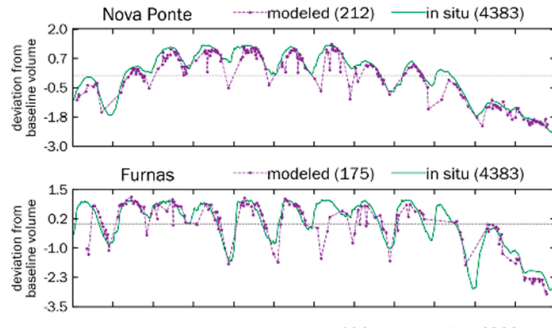

Chavantes - - modeled (196) - in situ (4383)
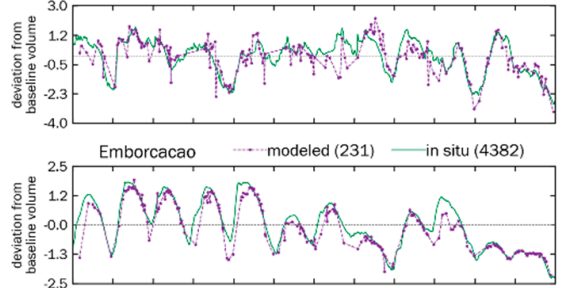

Iha Solteira --.-modeled (228) - in situ (4356)
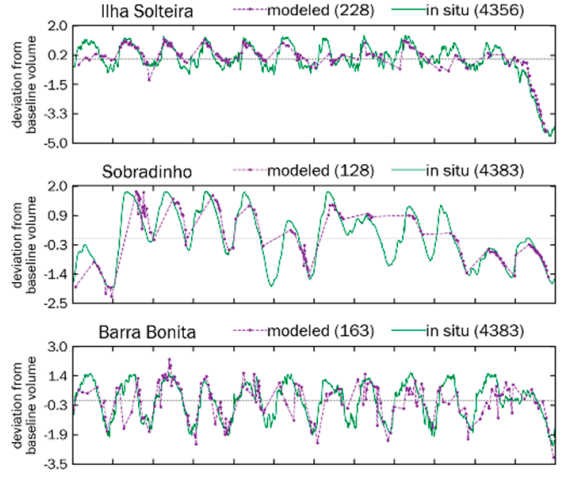

Sao Simao _....-..modeled (242) — —in situ (4383)
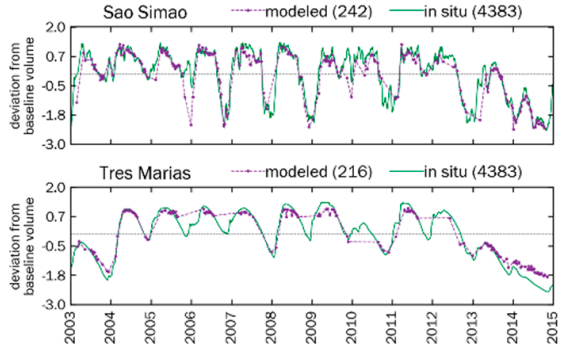

b)
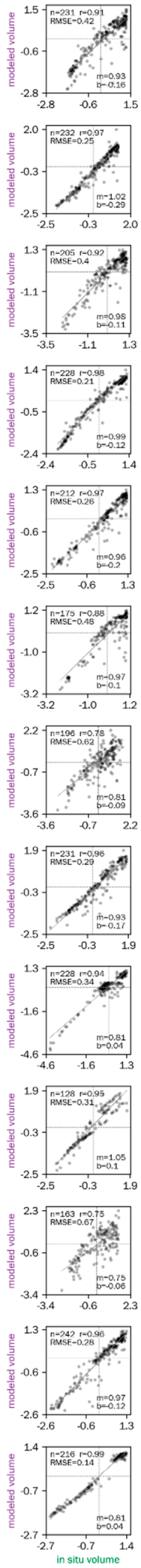

Figure A5. (a) Time series of difference between standardized reservoir volumes and each reservoir's baseline, pre-drought (i.e., median 2003-2011) volume for modeled (purple) and in situ (green) data, respectively; for dates without altimetry data, regression-based elevation values are used in modeling volume. (b) Linear regressions relating standardized in situ and modeled volumes on dates of mutual observation. Light grey lines in (a) and (b) indicate zero values on respective axes. All volume values are in $\mathrm{km}^{3}$. Time series and regressions for four select reservoirs are in Figure 9. 

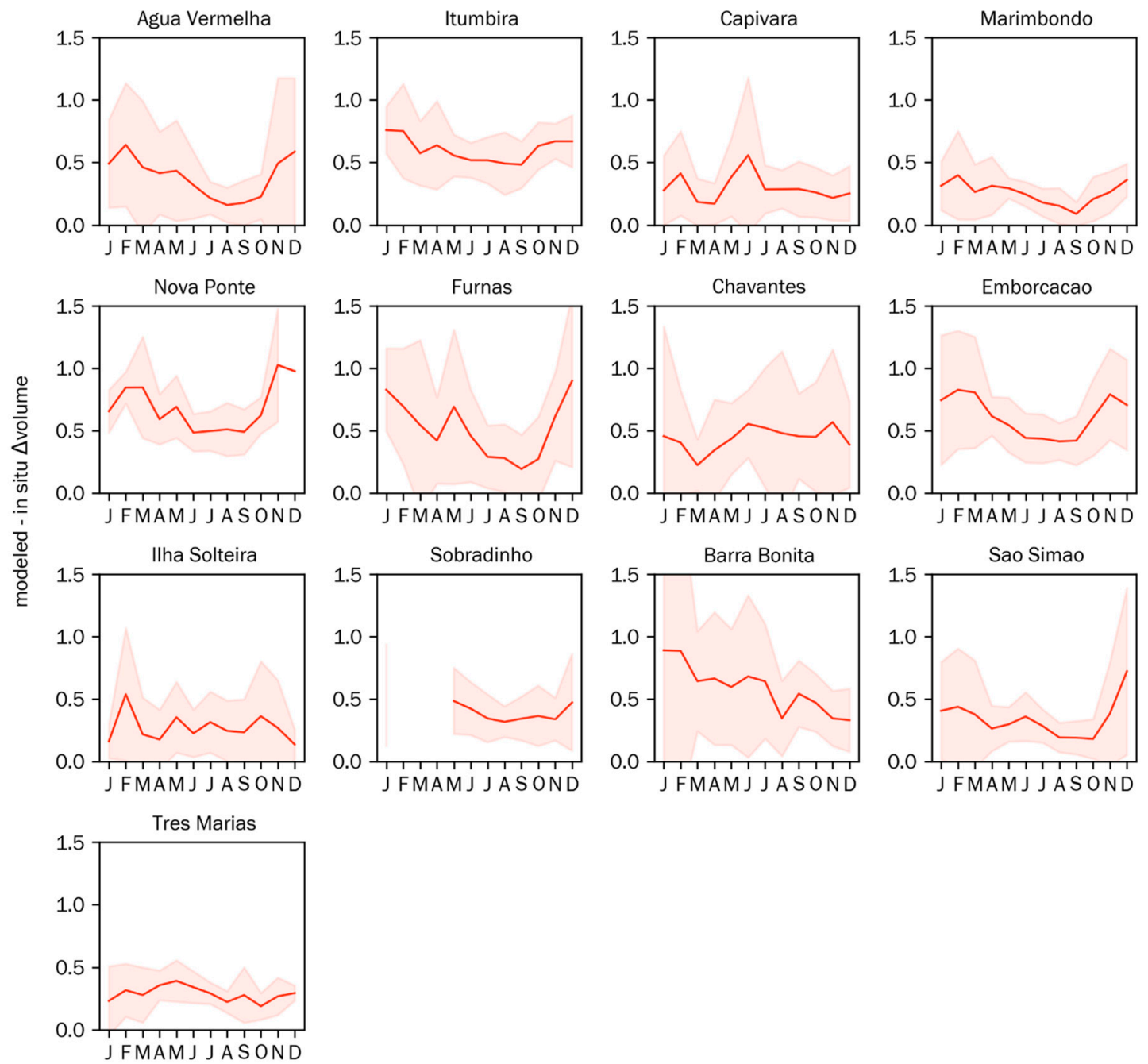

Figure A6. Mean monthly absolute difference between modeled and in situ standardized (unitless) volume changes (2003-2014; red line) with standard deviation range depicted (red field). Monthly comparisons for four select study reservoirs are in Figure 10.

\section{References}

1. Messager, M.L.; Lehner, B.; Grill, G.; Nedeva, I.; Schmitt, O. Estimating the volume and age of water stored in global lakes using a geo-statistical approach. Nat. Commun. 2016, 7, 13603. [CrossRef] [PubMed]

2. García, L.; Rodríguez, D.; Wijnen, M.; Pakulski, I. (Eds.) Earth Observation for Water Resources Management: Current Use and Future Opportunities for the Water Sector; The World Bank: Washington, DC, USA, 2016; ISBN 978-1-4648-0475-5.

3. Vörösmarty, C.J.; Sahagian, D. Anthropogenic Disturbance of the Terrestrial Water Cycle. Bioscience 2006, 50, 753. [CrossRef]

4. Zambon, R.C.; Barros, M.T.L.; Yeh, W.W.G. Impacts of the 2012-2015 Drought on the Brazilian Hydropower System. In Proceedings of the World Environmental and Water Resources Congress 2016, West Palm Beach, FL, USA, 22-26 May 2016; American Society of Civil Engineers: Reston, VA, USA, 2016; pp. 82-91.

5. Bastviken, D.; Tranvik, L.J.; Downing, J.A.; Crill, P.M.; Enrich-Prast, A. Freshwater methane emissions offset the continental carbon sink. Science 2011, 331. [CrossRef] [PubMed]

6. Fearnside, P.M. Do hydroelectric dams mitigate global warming? The case of Brazil's Curuá-Una Dam. Mitig. Adapt. Strateg. Glob. Chang. 2005, 10, 675-691. [CrossRef]

7. Kosten, S.; van den Berg, S.; Mendonça, R.; Paranaíba, J.R.; Roland, F.; Sobek, S.; Van Den Hoek, J.; Barros, N. Extreme drought boosts $\mathrm{CO} 2$ and $\mathrm{CH} 4$ emissions from reservoir drawdown areas. Inland Waters 2018, 8, 329-340. [CrossRef] 
8. Mendonça, R.; Kosten, S.; Sobek, S.; Barros, N.; Cole, J.J.; Tranvik, L.; Roland, F. Hydroelectric carbon sequestration. Nat. Geosci. 2012, 5, 838-840. [CrossRef]

9. Rudd, J.W.M.; Hecky, R.E.; Harris, R.; Kelly, C.A. Are hydroelectric reservoirs significant sources of greenhouse gases. Ambio 1993, 22, 246-248.

10. Duchemin, É.; Rudd, J.W.M.; St. Louis, V.L.; Kelly, C.A.; Rosenberg, D.M. Reservoir Surfaces as Sources of Greenhouse Gases to the Atmosphere: A Global Estimate. Bioscience 2006, 50, 766.

11. Knoll, L.B.; McKnight, D.M.; Larsen, S.; Dillon, P.; Fortino, K.; Cotner, J.B.; Striegl, R.G.; Prairie, Y.; Finlay, K.; Sherman, B.S.; et al. Lakes and reservoirs as regulators of carbon cycling and climate. Limnol. Oceanogr. 2011, $54,2298-2314$.

12. Lehner, B.; Liermann, C.R.; Revenga, C.; Vörömsmarty, C.; Fekete, B.; Crouzet, P.; Döll, P.; Endejan, M.; Frenken, K.; Magome, J.; et al. High-resolution mapping of the world's reservoirs and dams for sustainable river-flow management. Front. Ecol. Environ. 2011, 9, 494-502. [CrossRef]

13. Barros, N.; Cole, J.J.; Tranvik, L.J.; Prairie, Y.T.; Bastviken, D.; Huszar, V.L.M.; del Giorgio, P.; Roland, F. Carbon emission from hydroelectric reservoirs linked to reservoir age and latitude. Nat. Geosci. 2011, 4, 593-596. [CrossRef]

14. Deshmukh, C.; Serça, D.; Delon, C.; Tardif, R.; Demarty, M.; Jarnot, C.; Meyerfeld, Y.; Chanudet, V.; Guédant, P.; Rode, W.; et al. Physical controls on $\mathrm{CH} 4$ emissions from a newly flooded subtropical freshwater hydroelectric reservoir: Nam Theun 2. Biogeosciences 2014, 11, 4251-4269. [CrossRef]

15. Fearnside, P.M. Greenhouse gas emissions from a hydroelectric reservoir (Brazil's Tucuruídam) and the energy policy implications. Water Air Soil Pollut. 2002, 133, 69-96. [CrossRef]

16. Galy-Lacaux, C.; Delmas, R.; Kouadio, G.; Richard, S.; Gosse, P. Long-term greenhouse gas emissions from hydroelectric reservoirs in tropical forest regions. Glob. Biogeochem. Cycles 1999, 13, 503-517. [CrossRef]

17. Lima, I.B.T.; Ramos, F.M.; Bambace, L.A.W.; Rosa, R.R. Methane emissions from large dams as renewable energy resources: A developing nation perspective. Mitig. Adapt. Strateg. Glob. Chang. 2008, 13, 193-206. [CrossRef]

18. Deemer, B.R.; Harrison, J.A.; Li, S.; Beaulieu, J.J.; DelSontro, T.; Barros, N.; Bezerra-Neto, J.F.; Powers, S.M.; dos Santos, M.A.; Arie Vonk, J. Greenhouse Gas Emissions from Reservoir Water Surfaces: A New Global Synthesis. Bioscience 2016, 66, 949-964. [CrossRef]

19. Baup, F.; Frappart, F.; Maubant, J. Combining high-resolution satellite images and altimetry to estimate the volume of small lakes. Hydrol. Earth Syst. Sci. 2014, 18, 2007-2020. [CrossRef]

20. Crétaux, J.F.; Jelinski, W.; Calmant, S.; Kouraev, A.; Vuglinski, V.; Bergé-Nguyen, M.; Gennero, M.C.; Nino, F.; Abarca Del Rio, R.; Cazenave, A.; et al. SOLS: A lake database to monitor in the Near Real Time water level and storage variations from remote sensing data. Adv. Space Res. 2011, 47, 1497-1507. [CrossRef]

21. Ding, X.W.; Li, X.F. Monitoring of the water-area variations of Lake Dongting in China with ENVISAT ASAR images. Int. J. Appl. Earth Obs. Geoinf. 2011, 13, 894-901. [CrossRef]

22. Duan, Z.; Bastiaanssen, W.G.M. Estimating water volume variations in lakes and reservoirs from four operational satellite altimetry databases and satellite imagery data. Remote Sens. Environ. 2013, 134, 403-416. [CrossRef]

23. Gao, H.; Birkett, C.; Lettenmaier, D.P. Global monitoring of large reservoir storage from satellite remote sensing. Water Resour. Res. 2012, 48. [CrossRef]

24. Jiang, L.; Nielsen, K.; Andersen, O.B.; Bauer-Gottwein, P. CryoSat-2 radar altimetry for monitoring freshwater resources of China. Remote Sens. Environ. 2017, 200, 125-139. [CrossRef]

25. Smith, L.C.; Pavelsky, T.M. Remote sensing of volumetric storage changes in lakes. Earth Surf. Process. Landf. 2009, 34, 1353-1358. [CrossRef]

26. Tseng, K.H.; Shum, C.K.; Kim, J.W.; Wang, X.; Zhu, K.; Cheng, X. Integrating Landsat Imageries and Digital Elevation Models to Infer Water Level Change in Hoover Dam. IEEE J. Sel. Top. Appl. Earth Obs. Remote Sens. 2016, 9, 1696-1709. [CrossRef]

27. Zhang, J.; Xu, K.; Yang, Y.; Qi, L.; Hayashi, S.; Watanabe, M. Measuring Water Storage Fluctuations in Lake Dongting, China, by Topex/Poseidon Satellite Altimetry. Environ. Monit. Assess. 2006, 115, 23-37. [CrossRef]

28. Liebe, J.; van de Giesen, N.; Andreini, M. Estimation of small reservoir storage capacities in a semi-arid environment. Phys. Chem. Earth 2005, 30, 448-454. [CrossRef] 
29. Ogilvie, A.; Belaud, G.; Massuel, S.; Mulligan, M.; Le Goulven, P.; Calvez, R.; Ogilvie, A.; Belaud, G.; Massuel, S.; Mulligan, M.; et al. Assessing Floods and Droughts in Ungauged Small Reservoirs with Long-Term Landsat Imagery. Geosciences 2016, 6, 42. [CrossRef]

30. Singh, A.; Kumar, U.; Seitz, F. Remote Sensing of Storage Fluctuations of Poorly Gauged Reservoirs and State Space Model (SSM)-Based Estimation. Remote Sens. 2015, 7, 17113-17134. [CrossRef]

31. Wang, L.; Dessler, A.E. Instantaneous cloud overlap statistics in the tropical area revealed by ICESat/GLAS data. Geophys. Res. Lett. 2006, 33. [CrossRef]

32. Rodrigues, L.N.; Sano, E.E.; Steenhuis, T.S.; Passo, D.P. Estimation of small reservoir storage capacities with remote sensing in the Brazilian Savannah region. Water Resour. Manag. 2012, 26, 873-882. [CrossRef]

33. Sano, E.E.; Ferreira, L.G.; Asner, G.P.; Steinke, E.T. Spatial and temporal probabilities of obtaining cloud-free Landsat images over the Brazilian tropical savanna. Int. J. Remote Sens. 2007, 28, 2739-2752. [CrossRef]

34. Vermote, E.; Wolfe, R. MOD09GA MODIS/Terra Surface Reflectance Daily L2G Global 1kmand 500m SIN Grid V006 [Data set]; NASA EOSDIS Land Processes DAAC: Sioux Falls, SD, USA, 2015.

35. Zhang, S.; Gao, H.; Naz, B.S. Monitoring reservoir storage in South Asia from multisatellite remote sensing. Water Resour. Res. 2014, 50, 8927-8943. [CrossRef]

36. Chipman, J.W. A Multisensor Approach to Satellite Monitoring of Trends in Lake Area, Water Level, and Volume. Remote Sens. 2019, 11, 158. [CrossRef]

37. Hamilton, S.K.; Sippel, S.J.; Melack, J.M. Seasonal inundation patterns in two large savanna floodplains of South America: The Llanos de Moxos (Bolivia) and the Llanos del Orinoco (Venezuela and Colombia). Hydrol. Proc. 2004, 18, 2103-2116. [CrossRef]

38. Kang, S.; Hong, S.Y. Assessing Seasonal and Inter-Annual Variations of Lake Surface Areas in Mongolia during 2000-2011 Using Minimum Composite MODIS NDVI. PLoS ONE 2016, 11, e151395. [CrossRef]

39. Donchyts, G.; Baart, F.; Winsemius, H.; Gorelick, N.; Kwadijk, J.; Van De Giesen, N. Earth's surface water change over the past 30 years. Nat. Clim. Chang. 2016, 6, 810-813. [CrossRef]

40. Feyisa, G.L.; Meilby, H.; Fensholt, R.; Proud, S.R. Automated Water Extraction Index: A new technique for surface water mapping using Landsat imagery. Remote Sens. Environ. 2014, 140, 23-35. [CrossRef]

41. Feng, M.; Sexton, J.O.; Channan, S.; Townshend, J.R. A global, high-resolution (30-m) inland water body dataset for 2000: First results of a topographic-spectral classification algorithm. Int. J. Digit. Earth 2016, 9, 113-133. [CrossRef]

42. Mueller, N.; Lewis, A.; Roberts, D.; Ring, S.; Melrose, R.; Sixsmith, J.; Lymburner, L.; McIntyre, A.; Tan, P.; Curnow, S.; et al. Water observations from space: Mapping surface water from 25years of Landsat imagery across Australia. Remote Sens. Environ. 2016, 174, 341-352. [CrossRef]

43. Pekel, J.F.; Cottam, A.; Gorelick, N.; Belward, A.S. High-resolution mapping of global surface water and its long-term changes. Nature 2016, 540, 418-422. [CrossRef]

44. Alsdorf, D.E.; Rodríguez, E.; Lettenmaier, D.P. Measuring surface water from space. Rev. Geophys. $2007,45$. [CrossRef]

45. Avisse, N.; Tilmant, A.; François Müller, M.; Zhang, H. Monitoring small reservoirs' storage with satellite remote sensing in inaccessible areas. Hydrol. Earth Syst. Sci. 2017, 21, 6445-6459. [CrossRef]

46. Uebbing, B.; Kusche, J.; Forootan, E. Waveform retracking for improving level estimations from TOPEX/Poseidon, Jason-1, and Jason-2 altimetry observations over African lakes. IEEE Trans. Geosci. Remote Sens. 2015, 53, 2211-2224. [CrossRef]

47. Jiang, L.; Schneider, R.; Andersen, O.B.; Bauer-Gottwein, P. CryoSat-2 altimetry applications over rivers and lakes. Water 2017, 9, 211. [CrossRef]

48. Politi, E.; MacCallum, S.; Cutler, M.E.J.; Merchant, C.J.; Rowan, J.S.; Dawson, T.P. Selection of a network of large lakes and reservoirs suitable for global environmental change analysis using Earth Observation. Int. J. Remote Sens. 2016, 37, 3042-3060. [CrossRef]

49. Busker, T.; de Roo, A.; Gelati, E.; Schwatke, C.; Adamovic, M.; Bisselink, B.; Pekel, J.F.; Cottam, A. A global lake and reservoir volume analysis using a surface water dataset and satellite altimetry. Hydrol. Earth Syst. Sci. 2019, 23, 669-690. [CrossRef]

50. Narasimha Rao, P.V.; Sesha Sai, M.V.R. Cover: Clouds over land in Envisat ASAR C-band image. Int. J. Remote Sens. 2006, 27, 833-834. [CrossRef] 
51. Pipitone, C.; Maltese, A.; Dardanelli, G.; Brutto, M.L.; Loggia, G.L. Monitoring water surface and level of a reservoir using different remote sensing approaches and comparison with dam displacements evaluated via GNSS. Remote Sens. 2018, 10, 71. [CrossRef]

52. Ye, Z.; Liu, H.; Chen, Y.; Shu, S.; Wu, Q.; Wang, S. Analysis of water level variation of lakes and reservoirs in Xinjiang, China using ICESat laser altimetry data (2003-2009). PLoS ONE 2017, 12, e0183800. [CrossRef]

53. Getirana, A. Extreme Water Deficit in Brazil Detected from Space. J. Hydrometeorol. 2016, 17, 591-599. [CrossRef]

54. Nobre, C.A.; Marengo, J.A.; Seluchi, M.E.; Cuartas, L.A.; Alves, L.M. Some Characteristics and Impacts of the Drought and Water Crisis in Southeastern Brazil during 2014 and 2015. J. Water Resour. Prot. 2016, 08, 252-262. [CrossRef]

55. Marengo, J.A.; Alves, L.M.; Soares, W.R.; Rodriguez, D.A. Two Contrasting Severe Seasonal Extremes in Tropical South America in 2012: Flood in Amazonia and Drought in Northeast Brazil. J. Clim. 2013, 26, 9137-9154. [CrossRef]

56. Marengo, J.A.; Torres, R.R.; Alves, L.M. Drought in Northeast Brazil-Past, present, and future. Theor. Appl. Climatol. 2017, 129, 1189-1200. [CrossRef]

57. $\mathrm{Xu}, \mathrm{H}$. Modification of normalised difference water index (NDWI) to enhance open water features in remotely sensed imagery. Int. J. Remote Sens. 2006, 27, 3025-3033. [CrossRef]

58. Wang, X.; Cheng, X.; Gong, P.; Huang, H.; Li, Z.; Li, X. Earth science applications of ICESat/GLAS: A review. Int. J. Remote Sens. 2011, 32, 8837-8864. [CrossRef]

59. Phan, V.H.; Lindenbergh, R.; Menenti, M. ICESat derived elevation changes of Tibetan lakes between 2003 and 2009. Int. J. Appl. Earth Obs. Geoinf. 2012, 17, 12-22. [CrossRef]

60. Birkett, C.; Reynolds, C.; Beckley, B.; Doorn, B. From research to operations: The USDA global reservoir and lake monitor. In Coastal Altimetry; Springer-Verlag Berlin Heidelberg: Berlin, Germany, 2011; pp. 19-50. ISBN 9783642127953.

61. da Silva, J.S.; Calmant, S.; Seyler, F.; Rotunno Filho, O.C.; Cochonneau, G.; Mansur, W.J. Water levels in the Amazon basin derived from the ERS 2 and ENVISAT radar altimetry missions. Remote Sens. Environ. 2010, 114, 2160-2181. [CrossRef]

62. Frappart, F.; Calmant, S.; Cauhopé, M.; Seyler, F.; Cazenave, A. Preliminary results of ENVISAT RA-2-derived water levels validation over the Amazon basin. Remote Sens. Environ. 2006, 100, 252-264. [CrossRef]

63. Lee, H.; Shum, C.K.; Tseng, K.H.; Guo, J.Y.; Kuo, C.Y. Present-day lake level variation from envisat altimetry over the northeastern qinghai-tibetan plateau: Links with precipitation and temperature. Terr. Atmos. Ocean. Sci. 2011, 22, 169-175. [CrossRef]

64. Medina, C.E.; Gomez-Enri, J.; Alonso, J.J.; Villares, P. Water level fluctuations derived from ENVISAT Radar Altimeter (RA-2) and in-situ measurements in a subtropical waterbody: Lake Izabal (Guatemala). Remote Sens. Environ. 2008, 112, 3604-3617. [CrossRef]

65. Medina, C.; Gomez-Enri, J.; Alonso, J.J.; Villares, P. Water volume variations in Lake Izabal (Guatemala) from in situ measurements and ENVISAT Radar Altimeter (RA-2) and Advanced Synthetic Aperture Radar (ASAR) data products. J. Hydrol. 2010, 382, 34-48. [CrossRef]

66. Schwatke, C.; Dettmering, D.; Bosch, W.; Seitz, F. DAHITI-An innovative approach for estimating water level time series over inland waters using multi-mission satellite altimetry. Hydrol. Earth Syst. Sci. 2015, 19, 4345-4364. [CrossRef]

67. Siddique-E-Akbor, A.H.M.; Hossain, F.; Lee, H.; Shum, C.K. Inter-comparison study of water level estimates derived from hydrodynamic-hydrologic model and satellite altimetry for a complex deltaic environment. Remote Sens. Environ. 2011, 115, 1522-1531. [CrossRef]

68. Abshire, J.B.; Sun, X.; Riris, H.; Sirota, J.M.; McGarry, J.F.; Liiva, P.; Palm, S.; Yi, D. Geoscience Laser Altimeter System (GLAS) on the ICESat Mission: On-orbit measurement performance. Geophys. Res. Lett. 2005, 32. [CrossRef]

69. Hall, A.C.; Schumann, G.J.P.; Bamber, J.L.; Bates, P.D.; Trigg, M.A. Geodetic corrections to Amazon River water level gauges using ICESat altimetry. Water Resour. Res. 2012, 48. [CrossRef]

70. O'Loughlin, F.E.; Neal, J.; Yamazaki, D.; Bates, P.D. ICESat-derived inland water surface spot heights. Water Resour. Res. 2016, 52, 3276-3284. [CrossRef]

71. Swenson, S.; Wahr, J. Monitoring the water balance of Lake Victoria, East Africa, from space. J. Hydrol. 2009, 370, 163-176. [CrossRef] 
72. Wang, X.; Cheng, X.; Li, Z.; Huang, H.; Niu, Z.; Li, X.; Gong, P. Lake water footprint identification from time-series ICESat/GLAS data. IEEE Geosci. Remote Sens. Lett. 2012, 9, 333-337. [CrossRef]

73. Zhang, G.Q.; Xie, H.J.; Yao, T.D.; Kang, S.C. Water balance estimates of ten greatest lakes in China using ICESat and Landsat data. Chin. Sci. Bull. 2013, 58, 3815-3829. [CrossRef]

74. Okeowo, M.A.; Lee, H.; Hossain, F.; Getirana, A. Automated Generation of Lakes and Reservoirs Water Elevation Changes from Satellite Radar Altimetry. IEEE J. Sel. Top. Appl. Earth Obs. Remote Sens. 2017, 10, 3465-3481. [CrossRef]

75. Zwally, H.J.; Schutz, R.; Bentley, C.; Bufton, J.; Herring, T.; Minster, J.; Spinhirne, J.; Thomas, R. GLAS/ICESat L2 Global Land Surface Altimetry Data, Version 34. [GLA14]; NASA National Snow and Ice Data Center: Boulder, CO, USA, 2014. [CrossRef]

76. Frequently Asked Questions. Available online: https://nsidc.org/data/icesat/faq.html\#alt7 (accessed on 18 May 2018).

77. Taube, C.M. Three Methods for Computing the Volume of a Lake. In Manual of Fisheries Survey Methods II: With Periodic Updates; Schneider, J.C., Ed.; Michigan Department of Natural Resources: Lansing, MI, USA, 2000.

78. Ait-Kadi, M. Water for Development and Development for Water: Realizing the Sustainable Development Goals (SDGs) Vision. Aquat. Procedia 2016, 6, 106-110. [CrossRef]

79. Chadwick, R.; Good, P.; Martin, G.; Rowell, D.P. Large rainfall changes consistently projected over substantial areas of tropical land. Nat. Clim. Chang. 2016, 6, 177-181. [CrossRef]

80. Feng, X.; Porporato, A.; Rodriguez-Iturbe, I. Changes in rainfall seasonality in the tropics. Nat. Clim. Chang. 2013, 3, 811-815. [CrossRef]

81. De Paiva, R.C.D.; Collischonn, W.; Calmant, S.; Bulhões Mendes, C.A.; Bonnet, M.P.; Frappart, F.; Buarque, D.C. Large-scale hydrologic and hydrodynamic modeling of the Amazon River basin. Water Resour. Res. 2013, 49, 1226-1243. [CrossRef]

82. Getirana, A.C.; Boone, A.; Yamazaki, D.; Decharme, B.; Papa, F.; Mognard, N. The Hydrological Modeling and Analysis Platform (HyMAP): Evaluation in the Amazon Basin. J. Hydrometeorol. 2012, 13, 1641-1665. [CrossRef]

83. Jarihani, A.A.; Callow, J.N.; McVicar, T.R.; Van Niel, T.G.; Larsen, J.R. Satellite-derived Digital Elevation Model (DEM) selection, preparation and correction for hydrodynamic modelling in large, low-gradient and data-sparse catchments. J. Hydrol. 2015, 524, 489-506. [CrossRef]

84. Lu, S.; Ouyang, N.; Wu, B.; Wei, Y.; Tesemma, Z. Lake water volume calculation with time series remote-sensing images. Int. J. Remote Sens. 2013, 34, 7962-7973. [CrossRef]

85. Pillco Zolá, R.; Bengtsson, L. Three methods for determining the area-depth relationship of Lake Poopó, a large shallow lake in Bolivia. Lakes Reserv. 2007, 12, 275-284. [CrossRef]

86. Solander, K.C.; Reager, J.T.; Famiglietti, J.S. How well will the Surface Water and Ocean Topography (SWOT) mission observe global reservoirs? Water Resour. Res. 2016, 52, 2123-2140. [CrossRef]

87. Doll, P.; Fiedler, K.; Zhang, J. Global-scale analysis of river flow alterations due to water withdrawals and reservoirs. Hydrol. Earth Syst. Sci. 2009, 13, 2413-2432. [CrossRef]

88. Haddeland, I.; Skaugen, T.; Lettenmaier, D.P. Anthropogenic impacts on continental surface water fluxes. Geophys. Res. Lett. 2006, 33. [CrossRef]

89. Mateo, C.M.; Hanasaki, N.; Komori, D.; Tanaka, K.; Kiguchi, M.; Champathong, A.; Sukhapunnaphan, T.; Yamazaki, D.; Oki, T. Assessing the impacts of reservoir operation to floodplain inundation by combining hydrological, reservoir management, and hydrodynamic models. Water Resour. Res. 2014, 50, 7245-7266. [CrossRef]

90. Ji, L.; Zhang, L.; Wylie, B. Analysis of Dynamic Thresholds for the Normalized Difference Water Index. Photogramm. Eng. Remote Sens. 2013, 75, 1307-1317. [CrossRef]

91. Amitrano, D.; di Martino, G.; Iodice, A.; Mitidieri, F.; Papa, M.N.; Riccio, D.; Ruello, G. Sentinel-1 for monitoring reservoirs: A performance analysis. Remote Sens. 2014, 6, 10676-10693. [CrossRef]

92. Du, Y.; Zhang, Y.; Ling, F.; Wang, Q.; Li, W.; Li, X. Water bodies' mapping from Sentinel-2 imagery with Modified Normalized Difference Water Index at 10-m spatial resolution produced by sharpening the swir band. Remote Sens. 2016, 8, 354. [CrossRef]

93. Rucci, A.; Ferretti, A.; Monti Guarnieri, A.; Rocca, F. Sentinel 1 SAR interferometry applications: The outlook for sub millimeter measurements. Remote Sens. Environ. 2012, 120, 156-163. [CrossRef] 
94. Eilander, D.; Annor, F.O.; Iannini, L.; van de Giesen, N. Remotely sensed monitoring of small reservoir dynamics: A Bayesian approach. Remote Sens. 2014, 6, 1191-1210. [CrossRef]

95. Sippel, S.J.; Hamilton, S.K.; Melack, J.M.; Novo, E.M.M. Passive microwave observations of inundation area and the area/stage relation in the Amazon River floodplain. Int. J. Remote Sens. 1998, 19, 3055-3074. [CrossRef]

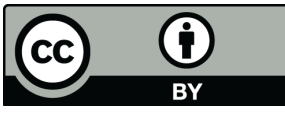

(C) 2019 by the authors. Licensee MDPI, Basel, Switzerland. This article is an open access article distributed under the terms and conditions of the Creative Commons Attribution (CC BY) license (http:/ / creativecommons.org/licenses/by/4.0/). 